\title{
Nutrient Use Efficiency Indices in Maize Hybrid as A Function of Various Rates of NPK in Mid Hills of Nepal
}

\author{
Nabin Rawal ${ }^{1,2, a, *}$, Keshab Raj Pande ${ }^{1, b}$, Renuka Shrestha ${ }^{3, c}$, Shree Prasad Vista ${ }^{2, d}$ \\ ${ }^{I}$ Department of Soil Science and Agri-engineering, Agriculture and Forestry University, Rampur, Chitwan, Nepal \\ ${ }^{2}$ National Soil Science Research Center, Nepal Agricultural Research Council, Khumaltar, Lalitpur, Nepal \\ ${ }^{3}$ National Agronomy Research Center, Nepal Agricultural Research Council, Lalitpur, Nepal \\ *Corresponding author
}

\section{A R T I C L E I N F O A B S T R A C T}

Research Article

Field experiments were conducted to evaluate yield and nutrient use efficiency in maize in response to various rates of nitrogen $(\mathrm{N})$, phosphorus $(\mathrm{P})$ and potassium $(\mathrm{K})$ in silty clay loam soil of Khumaltar, Nepal during 2019 and 2020. Three factorial randomized complete block designs with 27 treatment combinations were used in experiments, which were repeated three times. Three

Received : 14/08/2021

Accepted : 20/11/2021 factors were $\mathrm{N}$ levels $\left(150,180,210 \mathrm{~N} \mathrm{~kg} \mathrm{ha}^{-1}\right), \mathrm{P}$ levels $\left(40,60,80 \mathrm{P}_{2} \mathrm{O}_{5} \mathrm{~kg} \mathrm{ha}^{-1}\right)$, and $\mathrm{K}$ levels $(40$, $60,80 \mathrm{~K}_{2} \mathrm{O} \mathrm{kg} \mathrm{ha} \mathrm{kg}^{-1}$ ). The results recommend to revise fertilizer dose since $\mathrm{N} 210 \mathrm{~kg} \mathrm{ha}^{-1}$ and $\mathrm{K}_{2} \mathrm{O}$ $80 \mathrm{~kg} / \mathrm{ha}$ were optimum for increased maize production with grain yields of $10.95 \mathrm{t} \mathrm{ha}^{-1}$ and 10.54 $\mathrm{t} \mathrm{ha}^{-1}$, respectively. Partial factor productivity, partial nutrient budget, internal efficiency, physiological efficiency, recovery efficiency, and agronomic efficiency of NPK for hybrid maize

Keywords:

Grain yield

Hybrid maize

Nepal

NPK

Nutrient use efficiency were mostly influenced by nutrient levels. Application of higher rate of $\mathrm{P}$ and $\mathrm{K}$ fertilizer improved maize $\mathrm{N}$ efficiencies, and case was valid for $\mathrm{P}$ and $\mathrm{K}$ efficiencies. Maize was more responsive to $\mathrm{N}$ and $\mathrm{K}$ fertilizer and lower rate of $\mathrm{P}$ application limited efficient use of applied $\mathrm{N}$ and $\mathrm{K}$. To increase overall NUE, we recommend to revise dose of fertilizer for hybrid maize under mid hill condition of Nepal.

a sargamsagar10@gmail.com c@renuka.shrestha@gmail.com
iD https://orcid.org/0000-0001-6231-1232 D https://orcid.org/0000-0003-4011-0274 b@keshabrajpande@gmail.com spvista002@gmail.com (i) https://orcid.org/0000-0003-2744-4990 (iD) https://orcid.org/0000-0002-9008-7001

(c) (i) (8) This work is licensed under Creative Commons Attribution 4.0 International License

\section{Introduction}

Hybrid maize is a nutrient-responsive heavy feeder (Tetarwal et al., 2011) and has a high soil fertility requirement to achieve maximum yield (Uribelarrea et al., 2009). Hybrid maize requires an appropriate supply of nutrients, particularly nitrogen, phosphorus, and potassium, for improved and sustained yield (Asghar et al., 2010; Banerjee et al., 2014). In modern hybrid maize, nitrogen $(\mathrm{N})$, phosphorus $(\mathrm{P})$, and potassium $(\mathrm{K})$ play key roles in plant growth and development, chloroplast synthesis, protein synthesis (Jordan-Meille and Pellerin 2008; Bukhsh et al., 2012), and nutrient translocation and utilization (Minjian et al., 2007). The optimum amount of the elements in the soil cannot be used efficiently if these nutrients are deficient in plants. Maize crop response to nutrients varies greatly depending on soil and environmental conditions. The efficiency of nutrient usage increased until a certain amount of fertilizer application was reached, then curved as fertilizer application was increased further (Rehman et al., 2011). Improving nutrient efficiency is a noble goal and a serious challenge for the fertilizer industry and agriculture as a whole. To maximize crop yields and nutrient use efficiency, knowledge of the optimum fertilizer rate and crop nutrient requirements is essential for the benefits of the farmers and the environment.

Nutrient and its use efficiencies are the most significant constraint to increasing maize productivity. The partial factor productivity (PFP), partial nutrient budget (PNB), internal efficiency (IE), physiological efficiency (PE), recovery efficiency (RE), and agronomic efficiency (AE) of applied nutrients used to estimate nutrient use efficiencies (NUE) are commonly used in agronomic studies (Dobermann 2007; Snyder and Bruulsema 2007; Liu et al., 2011; Ray et al., 2017). To enhance both maize productivity and the environment, more effective $\mathrm{N}$ fertilizer use is required (Huang et al., 2018). Phosphorus deficiency in the soil decreases the nitrogen use efficiency (Delve et al., 2009). The use of K enhanced $\mathrm{N}$ absorption, resulting in a higher NUE (Brar et al., 2011). With reports averaging $33 \%$ of fertilizer nitrogen $(\mathrm{N})$ recovered by the 
crop, the NUE for world cereal production is poor (Raun and Johnson 1999). Just 30-50\% of applied nitrogen fertilizers (Smil 2002; Ladha et al., 2005) and 45\% of applied phosphorus fertilizers (Smil 2000) are estimated to be used for crops today. In the same way, fertilizer $\mathrm{N}$ recovery for corn might reach 65 percent (Ladha et al., 2005).

Phosphorus use efficiency in maize fields is crucial, as this nutrient is one of the most production-limiting elements (Coelho et al., 2008). Even if $\mathrm{P}$ is present in higher concentrations in soil, plant availability is often hampered due to the phosphate binding capacity of various soil types (Syers et al., 2008). Around 90\% of added fertilizer phosphorus is fixed in acidic soil containing iron and aluminum, making it inaccessible to plants (Potash and Phosphate 2003). Phosphorus use efficiency can range from $90 \%$ in well-managed agroecosystems (Syers et al., 2008 ) to $10-20 \%$ in highly phosphorus-fixing soils (Bolland and Gilkes 1998). Most agricultural crops recover $20-30 \%$ of applied $\mathrm{P}$ and in crops grown in soil with low potassium reserves, a realistic target of $40-60 \%$ potassium recovery efficiency has been reported under favorable conditions (Dobermann 2007). In cereal crops, global P use efficiency was reported to be only $16 \%$ (Dhillon et al., 2017). Most farmers in this region do not use mineral fertilizers, especially $\mathrm{K}$ fertilizers, and as a result, crop do not receive the sufficient nutrients they need for proper growth and grain production.

Although the maximum nutrient use efficiency is usually found at the lower parts of the yield response curve, where fertilizer inputs are lowest, fertilizer efficacy in increasing crop yields and optimizing farmer profitability should not be compromised purely for efficiency's sake (Ghosh et al., 2015). It's critical to find a balance between crop productivity and nutrient efficiency. In order to minimize losses and achieve better fertilizer practices, the variables considered in optimizing the use of nutrients, such as the correct dose, should be evaluated and examined (Fixen, 2010). The objective of this research was to evaluate how various levels of nitrogen, phosphorus, and potassium affected grain yield and NPK use efficiency in hybrid maize which helps to maximize the management practices for achieving higher yield.

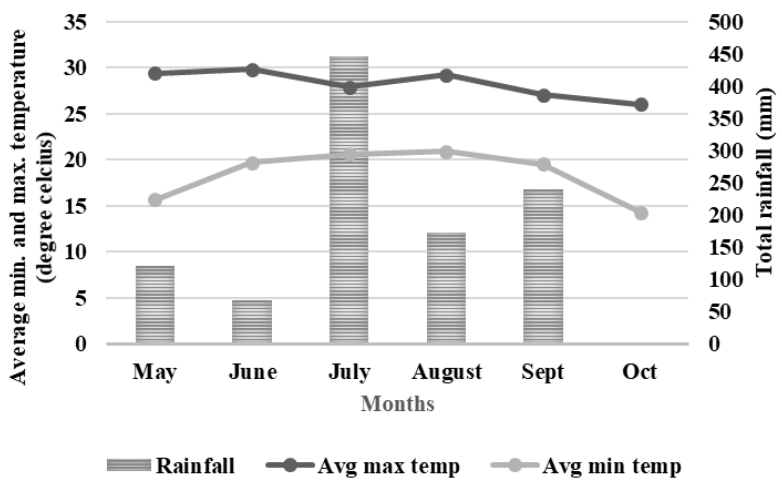

(a) 2019

\section{Materials and Methods}

\section{Experimental Site}

Field experiments were carried out during the monsoon seasons of 2019 and 2020 at National Agronomy Research Center and laboratory analysis and laboratory work was performed at National Soil Science Research Center, Khumaltar, Lalitpur, which situated in mid hill valley condition of Nepal (2739' North latitude, 85¹9' East longitude, 1285 above mean sea level). In the first season, meteorological data shows the highest monthly average maximum temperature of $29.7^{\circ} \mathrm{C}$ was faced by crop in June, 2019 that coincided with V6 to V8 stage of maize and the lowest temperature was $14.3^{\circ} \mathrm{C}$ in October, 2019. Similarly, in the second season, the highest average maximum temperature of $28.8^{\circ} \mathrm{C}$ was faced by maize crop during August, 2020 which coincided with silking to grain filling stage and the lowest average temperature was $15.7^{\circ} \mathrm{C}$ in October, 2020. Likewise, the precipitation of $1043.3 \mathrm{~mm}$ and $1149.6 \mathrm{~mm}$ was received by the first and the second maize crop, respectively which falls in month of July and coincided tasseling and silking stage of maize. The agrometeorological data were collected from National Agronomy Research Center, Khumaltar, Lalitpur, Nepal (Figure 1).

Before the field experiment, the soil in the experimental plot had a pH of 5.98 (acidic) and contained low organic matter $(2.01 \%)$, medium total nitrogen $(0.14 \%)$, high available phosphorus (478.6 $\mathrm{kg} \mathrm{ha}^{-1}$ ) and medium available potassium $\left(160.5 \mathrm{~kg} \mathrm{ha}^{-1}\right)$. With a silty clay loam soil texture, the average bulk density was $1.39 \mathrm{gm} \mathrm{cm}^{-3}$. To evaluate the fertility status, the soil was rated using Khatri Chhetri's (1991) soil value chart.

\section{Experimental Setup and Treatments}

The experiment was laid out in three factorial randomized complete block design (RCBD) consisting 27 treatments and three replications. The three factors consist three levels of nitrogen (150, 180 and $\left.210 \mathrm{~kg} \mathrm{ha}^{-1}\right)$, three levels of phosphorus (40, 60 and $80 \mathrm{~kg} \mathrm{ha}^{-1}$ ) and three levels of potassium (40,60 and $\left.80 \mathrm{~kg} \mathrm{ha}^{-1}\right)$ containing of 81 plots. Three nutrient omission treatments $(-\mathrm{N},-\mathrm{P}$, and $-\mathrm{K})$ of three replications were also included in the treatments to determine NUE. Individual plots size comprised of $10.5 \mathrm{~m}^{2}$ $(4.2 \mathrm{~m} \times 2.5 \mathrm{~m})$. Between two plots, a $0.7 \mathrm{~m}$ bunding was done, and the replication was separated by $1 \mathrm{~m}$.

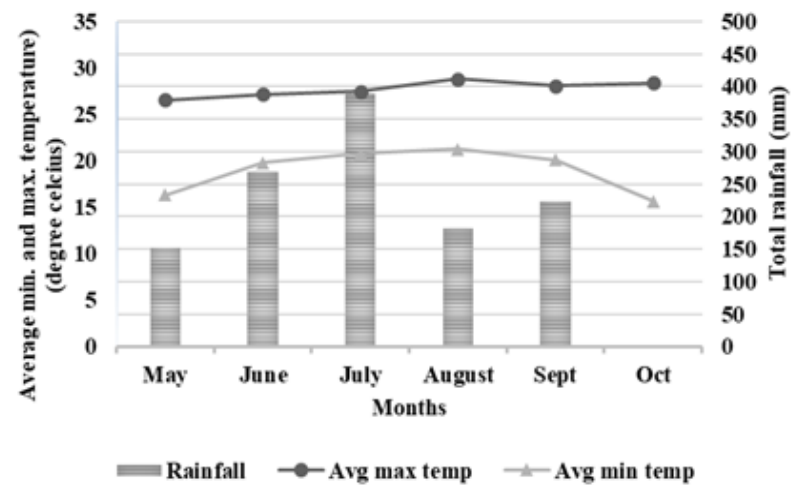

(b) 2020

Figure 1. Average monthly maximum and minimum temperature and rainfall during crop growing seasons in the study site 


\section{Crop Management}

On the 9th of May, 2019 and the 15th of May, 2020, maize seed was sown in well-prepared plots at a spacing of $60 \times 25 \mathrm{~cm}$, with two seeds per hill. Khumal Hybrid-2 was the hybrid maize variety used in the experiment. The fertilizers used to supply nitrogen, phosphorus, and potassium were urea $(46 \% \mathrm{~N})$, single super phosphate $\left(16 \% \mathrm{P}_{2} \mathrm{O}_{5}\right)$, and muriate of potash $\left(60 \% \mathrm{~K}_{2} \mathrm{O}\right)$. Phosphorus and potassium fertilizers were applied in full doses during land preparation while nitrogen was applied in three stages: $1 / 3$ as a basal application, $1 / 3$ at $30-35$ days after sowing, and $1 / 3$ at the tasseling stage of maize during both seasons. When the crop reached a height of $15 \mathrm{~cm}$, it was thinned to keep one plant per hill. To check weed-crop competition, the plot was hoed twice: once at knee height and again before tasseling. Furthermore, during different stages of maize development, all required agronomic practices were carried out consistently as required homogenously with proper care. Insecticides Fauji (Fipronil 0.3\% GR) @ 15 $\mathrm{kg} / \mathrm{ha}$ was used at the time of field preparation followed by spraying G-Sunami (Chlorpyrifos 50\% + Cypermethrin $5 \%$ EC) @ $1 \mathrm{ml} / \mathrm{L}$ to control cutworms. To control American Armyworm, Spinosad 45\% EC@0.3 ml/L (20 and 40 days after sowing) and Chlorantraniliprole $18.5 \%$ w/w @ 0.4 ml/L (30 days after sowing) were applied alternately thrice during the crop season. For weed management, Atrazine 50\% WP @ 1.0 kg a.i/ha (4 g/litre of water) was used as a pre-emergence treatment two days after sowing and Tembotrione 75\% EC @120 g a.i/ha (4 $\mathrm{ml} /$ litre of water) was used as a post-emergence treatment at 25 days after sowing. On September 22nd, 2019 and September 28th, 2020, the crop was manually harvested.

\section{Plant Sampling and Analysis}

Grain yield was measured on a subplot basis using a net plot area of $5.25 \mathrm{~m}^{2}$, adjusted for moisture content at $14 \%$, and converted to tons per hectare. Six plant samples (leaves, stem, tassel and husk) from net plot harvest were collected randomly at maturity of maize to make a composite sample and washed with tap water and then distilled water to extract adhering soil and dust. The grains were deshelled from six cobs and made a composite sample. The plant samples were oven dried at $70^{\circ} \mathrm{C}$ until constant weights were obtained, then grinded to a fine powder that passes through $0.2 \mathrm{~mm}$ sieve, and placed in polythene bags. The grain and stover samples were digested in di-acid of concentrated nitric acid $\left(\mathrm{HNO}_{3}\right)$ and hydrogen per oxide $\left(\mathrm{H}_{2} \mathrm{O}_{2}\right)$. Nitrogen was determined using Kjeldahl's digestion-distillation method (Bremner 1996), while $\mathrm{P}_{2} \mathrm{O}_{5}$ and $\mathrm{K}_{2} \mathrm{O}$ were estimated using VanadateMolybdate-phosphoric yellow color method and flame photometer method (Jackson 1973) from an extract prepared from digestion of acids. The nutrient accumulation in the above ground parts of the plant was calculated in $\mathrm{kg} \mathrm{ha}^{-1}$.

\section{Nutrient Use Efficiency Indices Calculation}

The PFP is measured in terms of crop yield per unit of nutrient applied. The PNB is expressed in terms of nutrient uptake by the harvested part per unit of nutrient added and is used to assess the long-term viability of a cropping system following Snyder and Bruulsema (2007). The amount of grain yield produced per kilogram of nutrient accumulation in above-ground plant dry matter is expressed as internal efficiency. The physiological efficiency is defined as the ratio of $\mathrm{kg}$ grain production to $\mathrm{kg}$ nutrient uptake in above-ground dry matter production. The increase in crop uptake of a nutrient in the aboveground portions of the plant in response to application of that nutrient is described as recovery efficiency. Agronomic efficiency is measured in terms of increased grain yield per unit of applied nutrient. The PE, PNB, IE, PE, RE, and AE were estimated using Dobermann (2007), Ray et al., (2017) and Liu et al., (2011) equations, as follows:

$$
\begin{aligned}
& \mathrm{TNU}=(\mathrm{GY} \times \mathrm{NC})+(\mathrm{SY} \times \mathrm{NCS}) \\
& \mathrm{PFP}_{\mathrm{X}}=\text { Grain yield } \mathrm{F}_{\mathrm{A}} / \text { Fertilizer applied } \\
& \mathrm{PNB}_{\mathrm{X}}=\text { Total nutrient uptake } \mathrm{F}_{\mathrm{A}} / \text { Fertilizer applied } \\
& \mathrm{IE}_{\mathrm{X}}=\text { Grain yield } \mathrm{F}_{\mathrm{A}} / \text { Total nutrient uptake } \mathrm{F}_{\mathrm{A}} \\
& \mathrm{PE}_{\mathrm{X}}=\frac{\left(\mathrm{GY} \mathrm{F}_{\mathrm{A}}-\mathrm{GY} \mathrm{F}_{0}\right)}{\left(\mathrm{TNU} \mathrm{F}_{\mathrm{A}}-\mathrm{TNU}_{0}\right)} \\
& \mathrm{RE}_{\mathrm{X}}=\frac{\left(\mathrm{TNU}_{\mathrm{A}}-\mathrm{TNU} \mathrm{F}_{0}\right)}{\mathrm{FA}} \times 100 \\
& \mathrm{AE}_{\mathrm{X}}=\frac{\mathrm{GY} \mathrm{F}_{\mathrm{A}}-\mathrm{GY} \mathrm{F}_{0}}{\mathrm{FA}}
\end{aligned}
$$

Where

TNU $=$ Total Nutrient uptake

$\mathrm{GY}=$ Grain yield $\left(\mathrm{kg} \mathrm{ha}^{-1}\right)$

$\mathrm{NC}=$ Nutrient concentration $(\%)$ in grain

$\mathrm{SY}=$ Straw yield $\left(\mathrm{kg} \mathrm{ha}^{-1}\right)$

NCS $=$ Nutrient concentration $(\%)$ in straw

$\mathrm{FA}=$ Fertilizer applied

$\mathrm{X}=\mathrm{N}, \mathrm{P}$, and $\mathrm{K} ; \mathrm{F}_{\mathrm{A}}=$ with fertilizer; $\mathrm{F}_{0}=$ without fertilizer, PFP, PNB, IE, PE, AE are expressed in $\mathrm{kg} \mathrm{kg}^{-1}$ whereas RE is expressed in percentage. All the applied fertilizers, yield of grain, total nutrient uptake is expressed in $\mathrm{kg}$.

\section{Statistical Analysis}

Grain yield as well as NUE indices were calculated as the average for the years 2019 and 2020. Data were subjected to analysis of variance (ANOVA) to evaluate the significance of treatment effect as given by Gomez and Gomez (1984). Means were compared by Duncan's Multiple Range Test (DMRT) at 5\% level of significance (Steel 1997)). The graphs were created using Microsoft Excel and Sigma plot software (version 12.0).

\section{Results}

\section{Maize Yield}

The two-year average results show that $\mathrm{N} 210 \mathrm{~kg} \mathrm{ha}^{-1}$ $\left(10.95 \mathrm{t} \mathrm{ha}^{-1}\right)$ and $\mathrm{K}_{2} \mathrm{O} 80 \mathrm{~kg} \mathrm{ha}^{-1}\left(10.54 \mathrm{t} \mathrm{ha}^{-1}\right)$ produced significantly higher grain yields followed by N180 $(9.77 \mathrm{t}$ $\mathrm{ha}^{-1}$ ) and $\mathrm{K}_{2} \mathrm{O} 60 \mathrm{~kg} \mathrm{ha}^{-1}\left(9.99 \mathrm{t} \mathrm{ha}^{-1}\right.$ ), respectively (Figure 2). The lowest grain yield of $9.21 \mathrm{t} \mathrm{ha}^{-1}$ and $9.39 \mathrm{t} \mathrm{ha}^{-1}$ was produced by $\mathrm{N} 150 \mathrm{~kg} \mathrm{ha}^{-1}$ and $\mathrm{K}_{2} \mathrm{O} 40 \mathrm{~kg} \mathrm{ha}^{-1}$. However, there was no substantial phosphorus response beyond 40 $\mathrm{kg} \mathrm{P}_{2} \mathrm{O}_{5} \mathrm{~kg} \mathrm{ha}^{-1}$. 


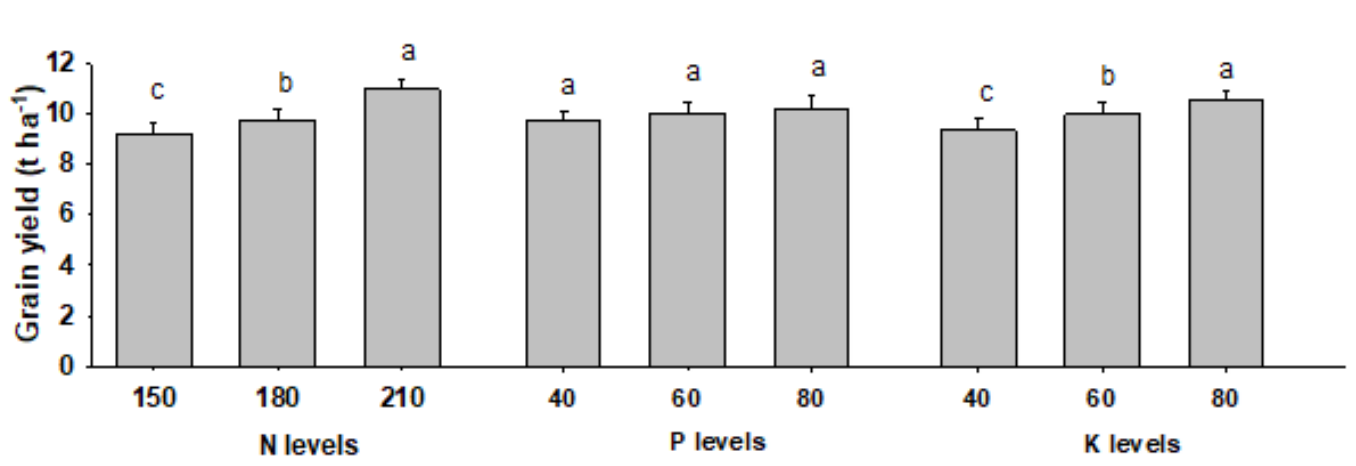

Figure 2. Grain yield of maize as affected by NPK levels (2019-2020).

Different small alphabetical letters indicate significant differences at $\mathrm{P}<0.05$ (otherwise statistically at par). Bars indicate mean with standard error.

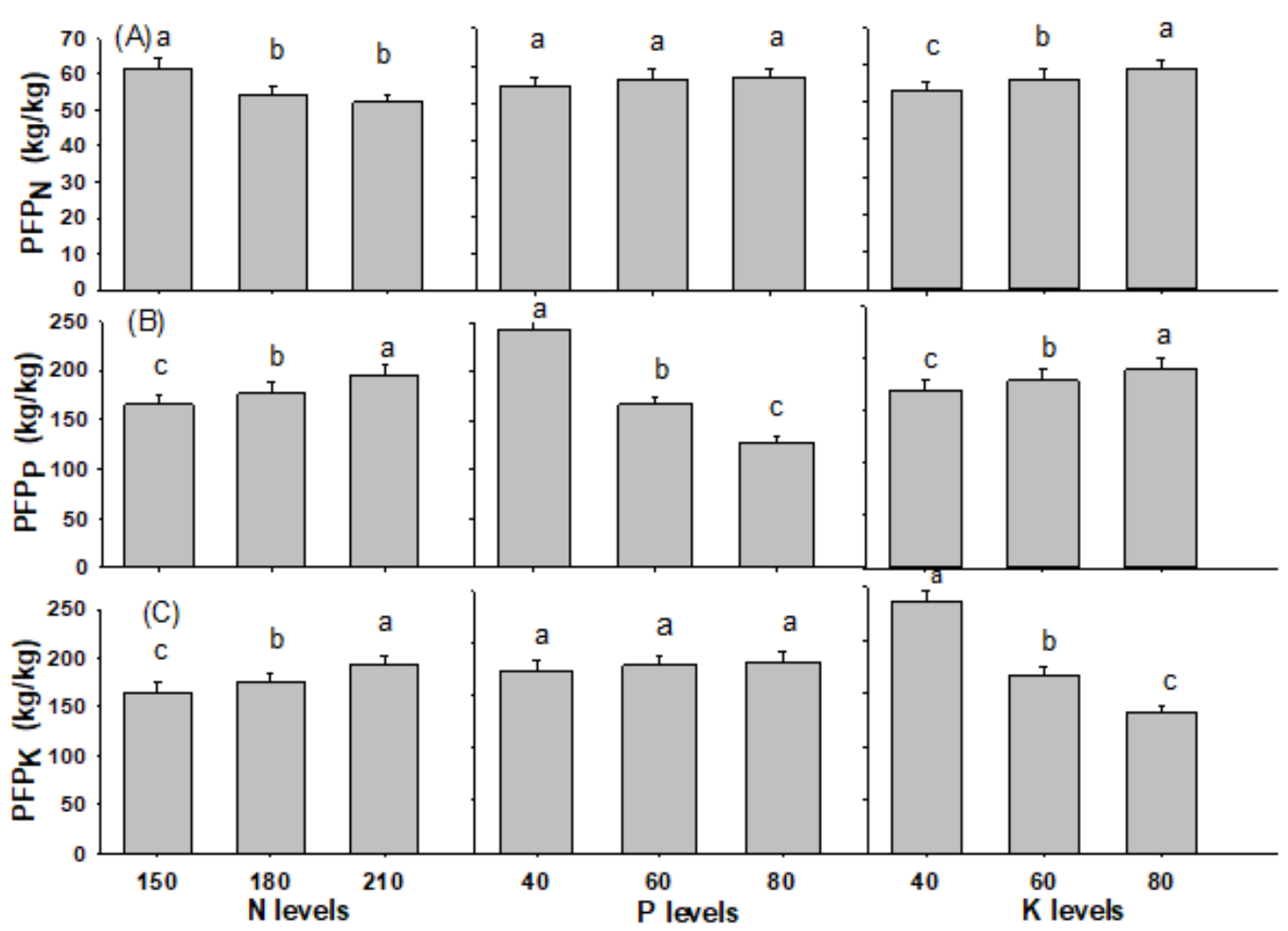

Figure 3. Partial factor productivity of hybrid maize (A) nitrogen (B) phosphorus (C) potassium as influenced by different levels of NPK fertilizer (2019-2020).

Different small alphabetical letters indicate significant differences at $\mathrm{P}<0.05$ (otherwise statistically at par). Bars indicate mean with standard error.

The interaction of $\mathrm{N} \times \mathrm{P}$ was found to be significant while all the other interactions: $\mathrm{N} \times \mathrm{K}, \mathrm{P} \times \mathrm{K}$ and $\mathrm{N} \times \mathrm{P} \times$ $\mathrm{K}$ was found to be non-significant on grain yield of maize (Table 1).

\section{Partial Factor Productivity}

The significantly higher $\operatorname{PFP}_{\mathrm{N}}\left(61.4 \mathrm{~kg} \mathrm{~kg}^{-1}\right)$ of maize was recorded with the application of $\mathrm{N} 150$ while the lowest $\left(52.1 \mathrm{~kg} \mathrm{~kg}^{-1}\right)$ was observed from the application of $\mathrm{N} 210 \mathrm{~kg} \mathrm{ha}^{-1}$ (Figure 3). With the higher $\mathrm{P}_{2} \mathrm{O}_{5}$ and $\mathrm{K}_{2} \mathrm{O}$ application rate of $80 \mathrm{~kg} \mathrm{ha}^{-1}$ each, higher $\operatorname{PFP}_{\mathrm{N}}$ (59.9 and $59.0 \mathrm{~kg} \mathrm{~kg}^{-1}$, respectively) were recorded while it decreased with decreasing nutrient rates. At the same time, the higher $\operatorname{PFP}_{\mathrm{P}}\left(194.8 \mathrm{~kg} \mathrm{~kg}^{-1}\right)$ and $\mathrm{PFP}_{\mathrm{K}}\left(194.2 \mathrm{~kg} \mathrm{~kg}^{-1}\right)$ were observed with the application of $\mathrm{N} 210 \mathrm{~kg} \mathrm{ha}^{-1}$ whereas lower values were recorded from low rates showing similar trends as that of $\mathrm{PFP}_{\mathrm{N}}$. The maximum $\mathrm{PFP}_{\mathrm{P}}$ was recorded by the use of $\mathrm{P}_{2} \mathrm{O}_{5} 40 \mathrm{~kg} \mathrm{ha}^{-1}\left(242.7 \mathrm{~kg} \mathrm{~kg}^{-1}\right)$ and $\mathrm{K}_{2} \mathrm{O} 80$ $\mathrm{kg} \mathrm{ha}^{-1}\left(181.7 \mathrm{~kg} \mathrm{~kg}^{-1}\right)$ while the lowest value was obtained with the application of $\mathrm{P}_{2} \mathrm{O}_{5} 80 \mathrm{~kg} / \mathrm{ha}\left(127.8 \mathrm{~kg} \mathrm{~kg}^{-1}\right)$ and $\mathrm{K}_{2} \mathrm{O} 40 \mathrm{~kg} / \mathrm{ha}\left(173.0 \mathrm{~kg} \mathrm{~kg}^{-1}\right)$. Similarly, significantly higher PFPP $\left(189.3 \mathrm{~kg} \mathrm{~kg}^{-1}\right)$ and PFP $_{\mathrm{K}}\left(234.9 \mathrm{~kg} \mathrm{~kg}^{-1}\right)$ of hybrid maize was recorded with the application of $\mathrm{P}_{2} \mathrm{O}_{5} 80$ $\mathrm{kg} \mathrm{ha}^{-1}$ and $\mathrm{K}_{2} \mathrm{O} 40 \mathrm{~kg} \mathrm{ha}^{-1}$ while the lowest $\left(169.0 \mathrm{~kg} \mathrm{~kg}^{-1}\right.$ and $131.8 \mathrm{~kg} \mathrm{~kg}^{-1}$ ) were observed from the application of $\mathrm{P}_{2} \mathrm{O}_{5} 40 \mathrm{~kg} \mathrm{ha}^{-1}$ and $\mathrm{K}_{2} \mathrm{O} 80 \mathrm{~kg} \mathrm{ha}^{-1}$, respectively.

\section{Partial Nutrient Budget}

Effect of nitrogen levels on $\mathrm{PNB}_{\mathrm{N}}$ of maize was significantly higher $\left(0.98 \mathrm{~kg} \mathrm{~kg}^{-1}\right)$ from the application of $\mathrm{N}$ $150 \mathrm{~kg} \mathrm{ha}^{-1}$ and the lowest $\left(0.95 \mathrm{~kg} \mathrm{~kg}^{-1}\right)$ was obtained from N $210 \mathrm{~kg} \mathrm{ha}^{-1}$ (Figure 4). However, the higher $\mathrm{PNB}_{\mathrm{N}}$ of $0.99 \mathrm{~kg}$ $\mathrm{kg}^{-1}$ and $1.03 \mathrm{~kg} \mathrm{~kg}^{-1}$ were recorded by the use of $\mathrm{P}_{2} \mathrm{O}_{5} 80 \mathrm{~kg}$ $\mathrm{ha}^{-1}$ and $\mathrm{K}_{2} \mathrm{O} 80 \mathrm{~kg} \mathrm{ha}^{-1}$, respectively while the lowest value of $0.9 \mathrm{~kg} \mathrm{~kg}^{-1}$ and $0.86 \mathrm{~kg} \mathrm{~kg}^{-1}$ were observed from the application of $\mathrm{P}_{2} \mathrm{O}_{5} 40 \mathrm{~kg} \mathrm{ha}^{-1}$ and $\mathrm{K}_{2} \mathrm{O} 40 \mathrm{~kg} \mathrm{ha}^{-1}$. Similarly, significantly higher $P_{N} B_{P}\left(2.07 \mathrm{~kg} \mathrm{~kg}^{-1}\right.$ and $\left.1.97 \mathrm{~kg} \mathrm{~kg}^{-1}\right)$ was recorded with the application of $210 \mathrm{~kg} \mathrm{ha}^{-1}$ and $\mathrm{K}_{2} \mathrm{O} 80 \mathrm{~kg}$ 
$\mathrm{ha}^{-1}$, respectively while the lowest of $1.59 \mathrm{~kg} \mathrm{~kg}^{-1}$ and $1.648 \mathrm{~kg}$ $\mathrm{kg}^{-1}$ were observed from the application of $\mathrm{N} 150 \mathrm{~kg} \mathrm{ha}^{-1}$ and $\mathrm{K}_{2} \mathrm{O} 40 \mathrm{~kg} \mathrm{ha}^{-1}$, respectively. Higher value of $\operatorname{PNB}_{\mathrm{P}}(2.37 \mathrm{~kg}$ $\mathrm{kg}^{-1}$ ) was recorded with the application of $\mathrm{P}_{2} \mathrm{O}_{5} 40 \mathrm{~kg} \mathrm{ha}^{-1}$ and while the lowest $\left(1.35 \mathrm{~kg} \mathrm{~kg}^{-1}\right)$ was observed from application of $\mathrm{P}_{2} \mathrm{O}_{5} 80 \mathrm{~kg} \mathrm{ha}^{-1}$.

At the same time, significantly greater value of $\mathrm{PNB}_{\mathrm{K}}$ (1.89 kg kg-1 and $1.73 \mathrm{~kg} \mathrm{~kg}^{-1}$ ) in maize was reported with the application of $\mathrm{N} 210 \mathrm{~kg} \mathrm{ha}^{-1}$ and $\mathrm{P}_{2} \mathrm{O}_{5} 80 \mathrm{~kg} \mathrm{ha}^{-1}$ while the smallest value of $1.44 \mathrm{~kg} \mathrm{~kg}^{-1}$ and $1.54 \mathrm{~kg} \mathrm{~kg}^{-1}$ were found from the application of $\mathrm{N} @ 150 \mathrm{~kg} \mathrm{ha}^{-1}$ and $\mathrm{P}_{2} \mathrm{O}_{5} 40$ $\mathrm{kg} \mathrm{ha}^{-1}$, respectively. The effect of $\mathrm{K}$ levels on maize $\mathrm{PNB}_{\mathrm{K}}$ was significantly higher $\left(2.1 \mathrm{~kg} \mathrm{~kg}^{-1}\right)$ when $\mathrm{K}_{2} \mathrm{O} 40 \mathrm{~kg} \mathrm{ha}^{-1}$ was applied, and was the lowest $\left(1.29 \mathrm{~kg} \mathrm{~kg}^{-1}\right)$ when $\mathrm{K}_{2} \mathrm{O}$ $80 \mathrm{~kg} \mathrm{ha}^{-1}$ was applied.

\section{Internal Efficiency}

The significantly higher $\operatorname{IE}_{\mathrm{N}}\left(63.1 \mathrm{~kg} \mathrm{~kg}^{-1}, 60.9 \mathrm{~kg} \mathrm{~kg}\right.$ ${ }^{1}$ and $61.5 \mathrm{~kg} \mathrm{~kg}^{-1}$ ) was recorded with the application of $\mathrm{N}$ $150 \mathrm{~kg} \mathrm{ha}^{-1}, \mathrm{P}_{2} \mathrm{O}_{5} 40 \mathrm{~kg} \mathrm{ha}^{-1}$ and $\mathrm{K}_{2} \mathrm{O} 40 \mathrm{~kg} \mathrm{ha}^{-1}$, respectively while the lowest values were observed from the application of $\mathrm{N} 210 \mathrm{~kg} \mathrm{ha}^{-1}, \mathrm{P}_{2} \mathrm{O}_{5} 80 \mathrm{~kg} \mathrm{ha}^{-1}$ and $\mathrm{K}_{2} \mathrm{O}$ $80 \mathrm{~kg} \mathrm{ha}^{-1}\left(55.4 \mathrm{~kg} \mathrm{~kg}^{-1}, 57.6 \mathrm{~kg} \mathrm{~kg}^{-1}\right.$ and $57.7 \mathrm{~kg} \mathrm{~kg}^{-1}$, respectively) (Figure 5). The application of $\mathrm{N} 150 \mathrm{~kg} \mathrm{ha}^{-1}$, $\mathrm{P}_{2} \mathrm{O}_{5} 40 \mathrm{~kg} \mathrm{ha}^{-1}$ and $\mathrm{K}_{2} \mathrm{O} 40 \mathrm{~kg} \mathrm{ha}^{-1}$ resulted in the higher IE $\left(102.2 \mathrm{~kg} \mathrm{~kg}^{-1}, 102.2 \mathrm{~kg} \mathrm{~kg}^{-1}\right.$ and $\left.100.9 \mathrm{~kg} \mathrm{~kg}^{-1}\right)$ while the lowest value of $\operatorname{IE}_{P}\left(94.2 \mathrm{~kg} \mathrm{~kg}^{-1}, 94.1 \mathrm{~kg} \mathrm{~kg}^{-1}\right.$ and 95.8 $\mathrm{kg} \mathrm{kg}^{-1}$ ) was found from the application of $\mathrm{N} 210 \mathrm{~kg} \mathrm{ha}^{-1}$, $\mathrm{P}_{2} \mathrm{O}_{5} 80 \mathrm{~kg} \mathrm{ha}^{-1}$ and $\mathrm{K}_{2} \mathrm{O} 80 \mathrm{~kg} \mathrm{ha}^{-1}$, respectively, in Khumal hybrid-2 maize.
Similarly, higher $\mathrm{IE}_{\mathrm{K}}\left(118.0 \mathrm{~kg} \mathrm{~kg}^{-1}, 119.0 \mathrm{~kg} \mathrm{~kg}^{-1}\right.$ and $120.9 \mathrm{~kg} \mathrm{~kg}^{-1}$ ) was recorded with the application of $\mathrm{N} 150$ $\mathrm{kg} \mathrm{ha}^{-1}, \mathrm{P}_{2} \mathrm{O}_{5} 40 \mathrm{~kg} \mathrm{ha}^{-1}$ and $\mathrm{K}_{2} \mathrm{O} 40 \mathrm{~kg} \mathrm{ha}^{-1}$, respectively while the lowest value of $108.1 \mathrm{~kg} \mathrm{~kg}^{-1}, 107.7 \mathrm{~kg} \mathrm{~kg}^{-1}$ and $107.9 \mathrm{~kg} \mathrm{~kg}^{-1}$ were observed from the application of $\mathrm{N} 210$ $\mathrm{kg} \mathrm{ha}^{-1}, \mathrm{P}_{2} \mathrm{O}_{5} 80 \mathrm{~kg} \mathrm{ha}^{-1}$ and $\mathrm{K}_{2} \mathrm{O} 80 \mathrm{~kg} \mathrm{ha}^{-1}$, respectively.

\section{Physiological Efficiency}

The significantly higher $\mathrm{PE}_{\mathrm{N}}\left(46.2 \mathrm{~kg} \mathrm{~kg}^{-1}\right)$ was obtained with the application of $\mathrm{N} 150 \mathrm{~kg} \mathrm{ha}^{-1}$ and the lowest were found with the application of $\mathrm{N} 210 \mathrm{~kg} \mathrm{ha}^{-1}$ $\left(40.3 \mathrm{~kg} \mathrm{~kg}^{-1}\right)$ whereas the application of $\mathrm{P}$ and $\mathrm{K}$ rates were found to be non-significant on $\mathrm{PE}_{\mathrm{N}}$ (Figure 6). The maximum $\mathrm{PE}_{\mathrm{N}}$ (45.4 $\mathrm{kg} \mathrm{kg}^{-1}$ and $45.1 \mathrm{~kg} \mathrm{~kg}^{-1}$ ) were recorded with the application of $\mathrm{P}_{2} \mathrm{O}_{5} 40 \mathrm{~kg} \mathrm{ha}^{-1}$ and $\mathrm{K}_{2} \mathrm{O}$ $40 \mathrm{~kg} \mathrm{ha}^{-1}$, respectively while the lowest $\mathrm{PE}_{\mathrm{N}}\left(41.8 \mathrm{~kg} \mathrm{~kg}^{-1}\right.$ and $42.3 \mathrm{~kg} \mathrm{~kg}^{-1}$ ) was observed from the application of $\mathrm{P}_{2} \mathrm{O}_{5} 80 \mathrm{~kg} \mathrm{ha}^{-1}$ and $\mathrm{K}_{2} \mathrm{O} 80 \mathrm{~kg} \mathrm{ha}^{-1}$.

Similarly, application of $\mathrm{N} 150 \mathrm{~kg} \mathrm{ha}^{-1}, \mathrm{P}_{2} \mathrm{O}_{5} 40 \mathrm{~kg} \mathrm{ha}^{-1}$ and $\mathrm{K}_{2} \mathrm{O} 40 \mathrm{~kg} \mathrm{ha}^{-1}$ resulted the higher $\mathrm{PE}_{\mathrm{P}}\left(115.6 \mathrm{~kg} \mathrm{~kg}^{-1}\right.$, $119.9 \mathrm{~kg} \mathrm{~kg}^{-1}$ and $111.1 \mathrm{~kg} \mathrm{~kg}^{-1}$, respectively) whereas the lowest $\mathrm{PE}_{\mathrm{P}}\left(94.3 \mathrm{~kg} \mathrm{~kg}^{-1}, 79.9 \mathrm{~kg} \mathrm{~kg}^{-1}\right.$ and $101.9 \mathrm{~kg} \mathrm{~kg}^{-1}$ ) was observed with $\mathrm{N} 210 \mathrm{~kg} \mathrm{ha}^{-1}, \mathrm{P}_{2} \mathrm{O}_{5} 80 \mathrm{~kg} \mathrm{ha}^{-1}$ and $\mathrm{K}_{2} \mathrm{O}$ $80 \mathrm{~kg} \mathrm{ha}^{-1}$. The maize plant recorded the greater value of $\mathrm{PE}_{\mathrm{K}}$ with the use of $\mathrm{N} 150 \mathrm{~kg} \mathrm{ha}^{-1}\left(156.4 \mathrm{~kg} \mathrm{~kg}^{-1}\right), \mathrm{P}_{2} \mathrm{O}_{5} 40$ $\mathrm{kg} \mathrm{ha}^{-1}\left(161.1 \mathrm{~kg} \mathrm{~kg}^{-1}\right)$ and $\mathrm{K}_{2} \mathrm{O} 40 \mathrm{~kg} \mathrm{ha}^{-1}\left(161.2 \mathrm{~kg} \mathrm{~kg}^{-1}\right)$ while $\mathrm{PE}_{\mathrm{K}}$ of $117.7 \mathrm{~kg} \mathrm{~kg}^{-1}, 124.9 \mathrm{~kg} \mathrm{~kg}^{-1}$ and $122.5 \mathrm{~kg} \mathrm{~kg}^{-1}$ were recorded the lowest with the application of $\mathrm{N} 210 \mathrm{~kg} \mathrm{ha}^{-1}$, $\mathrm{P}_{2} \mathrm{O}_{5} 60 \mathrm{~kg} \mathrm{ha}^{-1}$ and $\mathrm{K}_{2} \mathrm{O} 80 \mathrm{~kg} \mathrm{ha}^{-1}$, respectively.

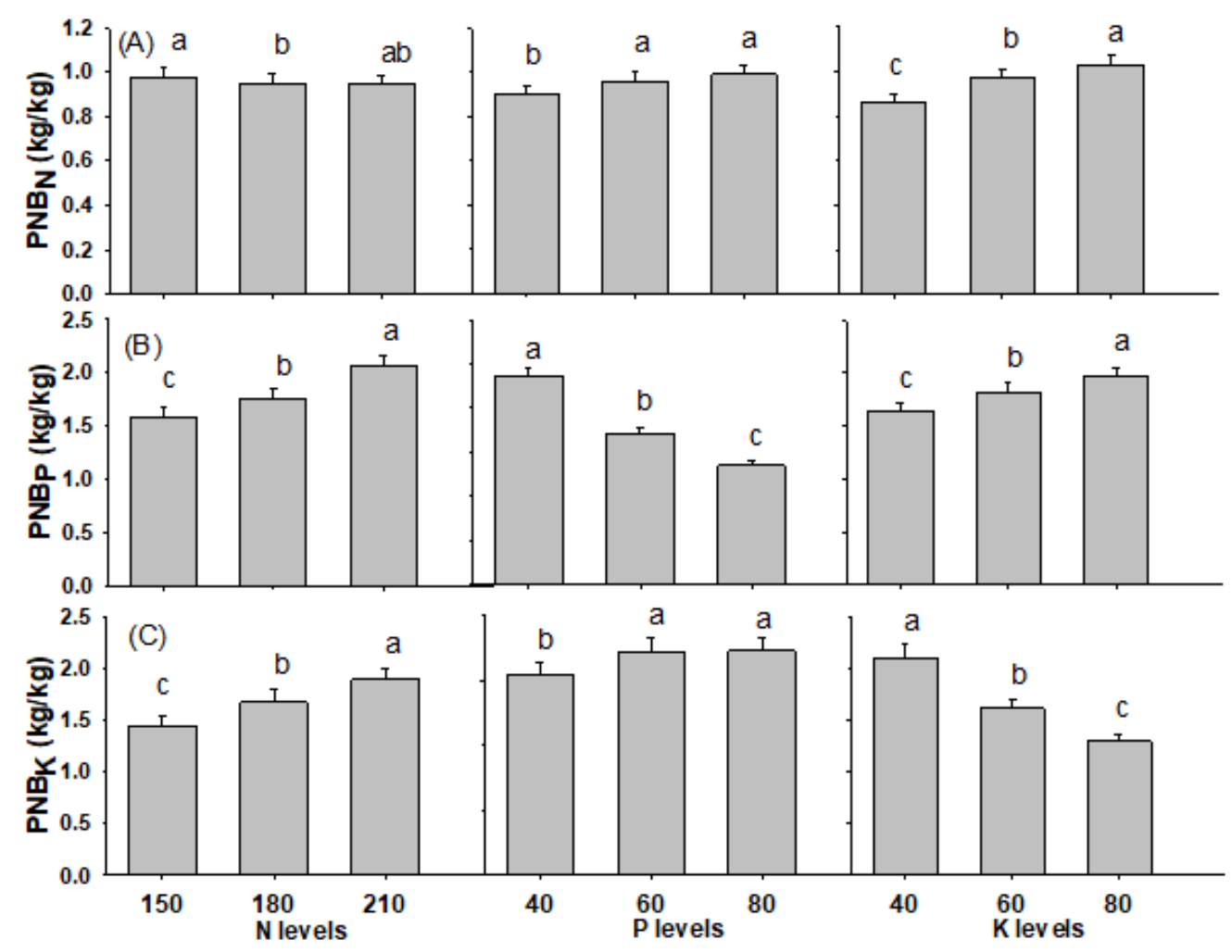

Figure 4. Partial Nutrient Budget of hybrid maize (A) nitrogen (B) phosphorus (C) potassium as influenced by different levels of NPK fertilizer (2019-2020).

Different small alphabetical letters indicate significant differences at $\mathrm{P}<0.05$ (otherwise statistically at par). Bars indicate mean with standard error. 


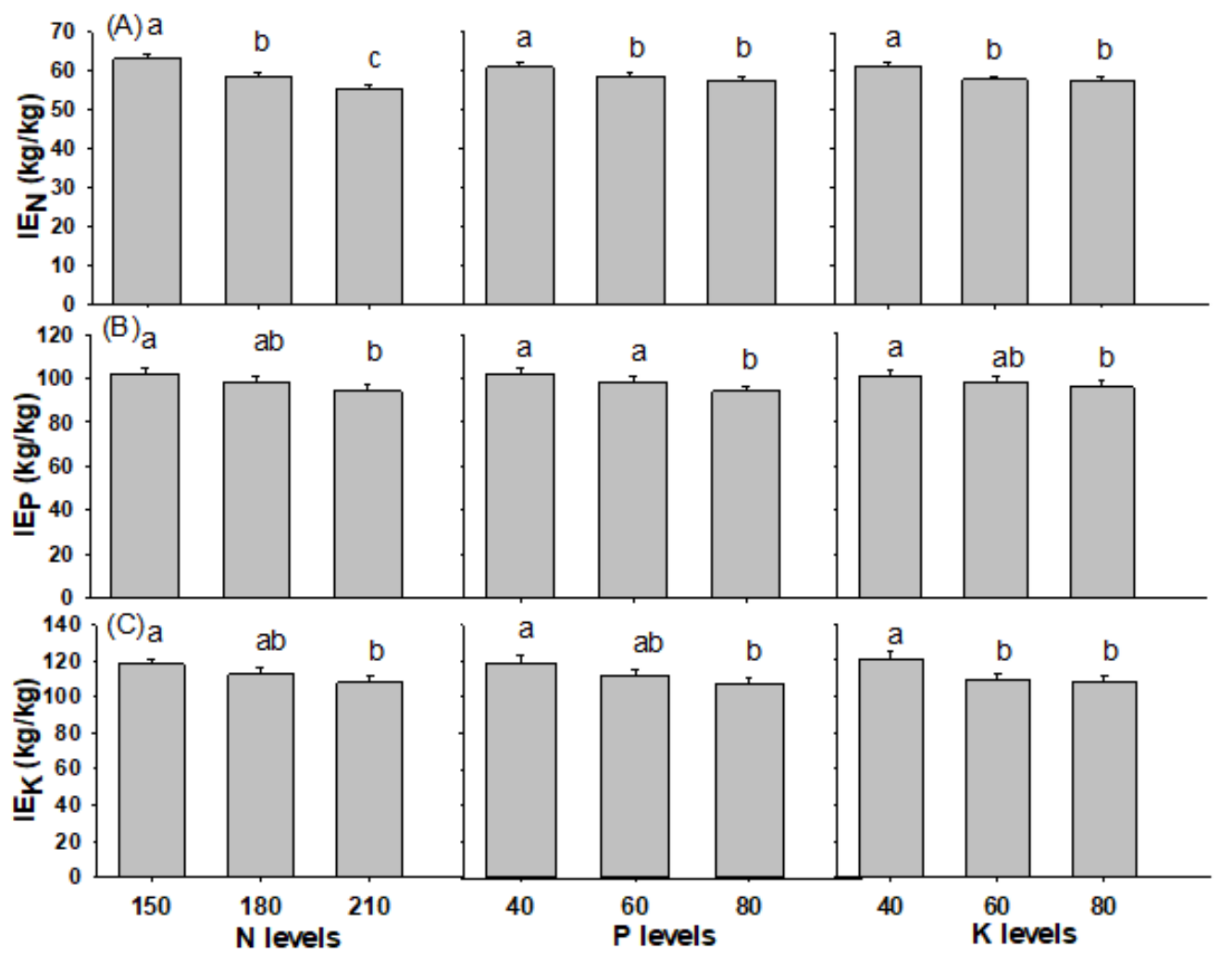

Figure 5. Internal Efficiency of hybrid maize (A) nitrogen (B) phosphorus (C) potassium as influenced by different levels of NPK fertilizer (2019-2020).

Different small alphabetical letters indicate significant differences at $\mathrm{P}<0.05$ (otherwise statistically at par). Bars indicate mean with standard error.

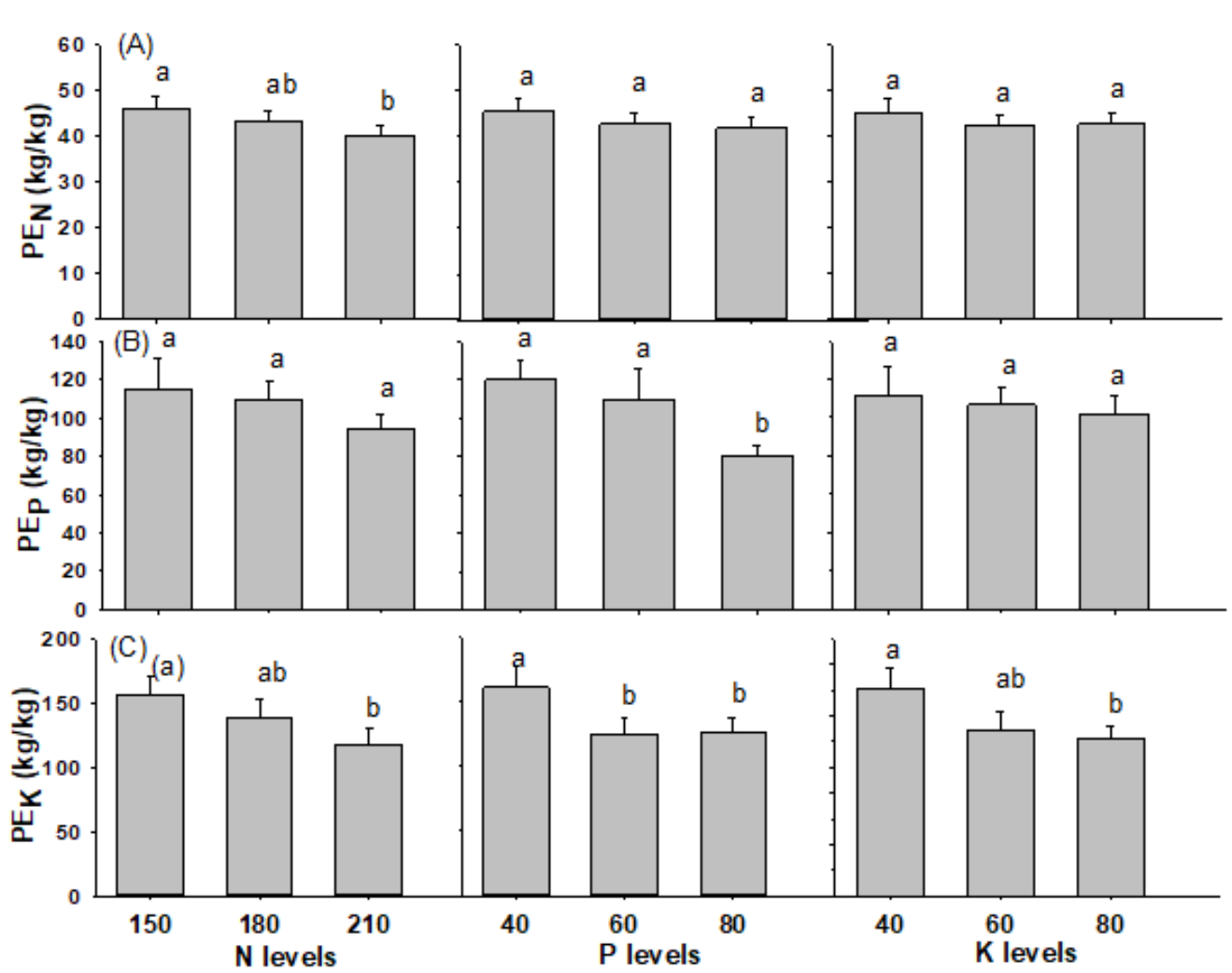

Figure 6. Physiological Efficiency of hybrid maize (A) nitrogen (B) phosphorus (C) potassium as influenced by different levels of NPK fertilizer (2019-2020).

Different small alphabetical letters indicate significant differences at $\mathrm{P}<0.05$ (otherwise statistically at par). Bars indicate mean with standard error. 

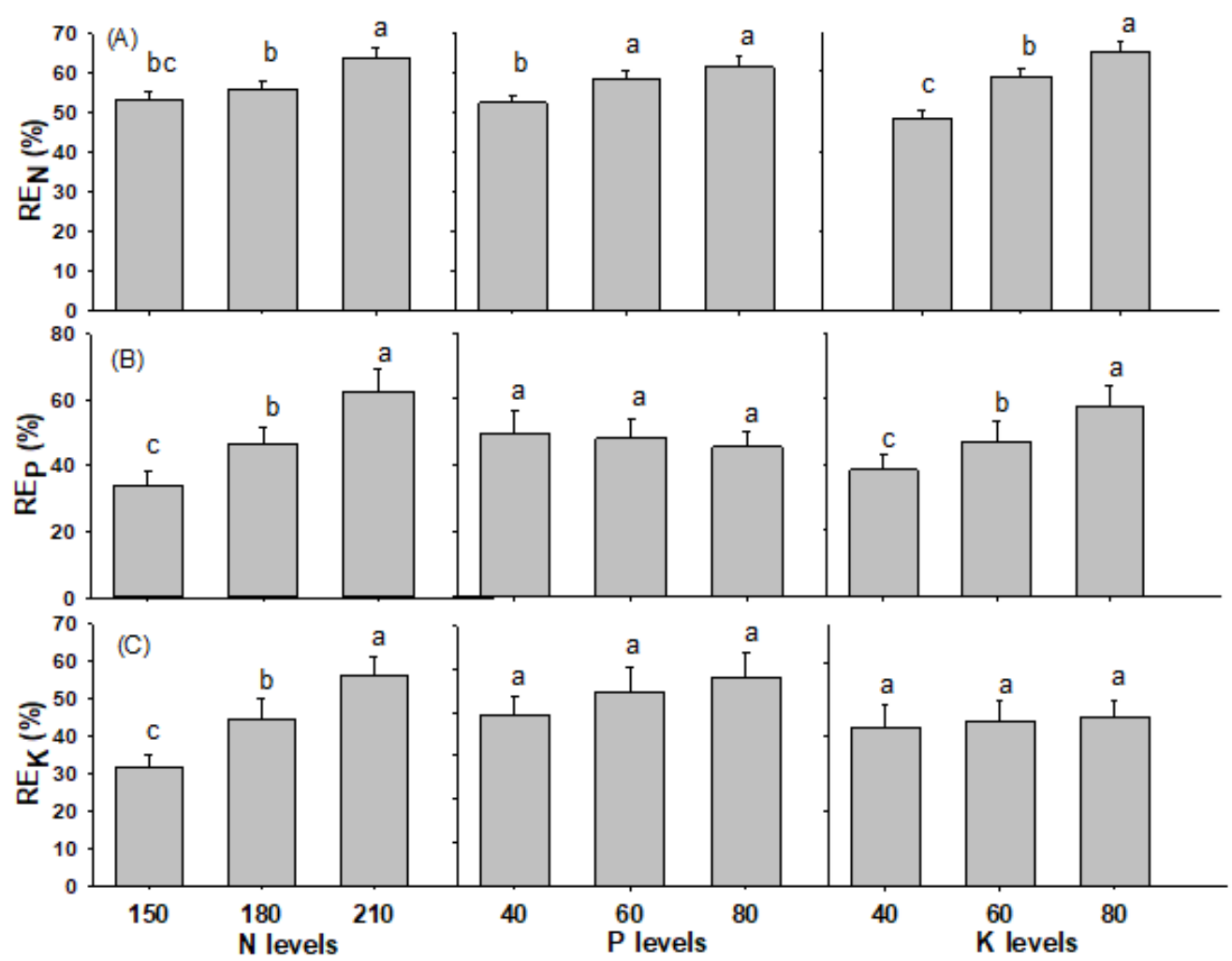

Figure 7. Recovery Efficiency of hybrid maize (A) nitrogen (B) phosphorus (C) potassium as influenced by different levels of NPK fertilizer (2019-2020).

Different small alphabetical letters indicate significant differences at $\mathrm{P}<0.05$ (otherwise statistically at par). Bars indicate mean with standard error.

\section{Recovery Efficiency}

Maize showed the highest $\mathrm{RE}_{\mathrm{N}}$ when $\mathrm{N} 210 \mathrm{~kg} \mathrm{ha}^{-1}$ $\mathrm{P}_{2} \mathrm{O}_{5} 80 \mathrm{~kg} \mathrm{ha}^{-1}$ and $\mathrm{K}_{2} \mathrm{O} 80 \mathrm{~kg} \mathrm{ha}^{-1}$ was applied $(63.5 \%$, $61.4 \%$ and $65.1 \%$, respectively), while lowest value of $53.0 \%, 52.3 \%$ and $48.4 \%$ was obtained with the application of $\mathrm{N} 150 \mathrm{~kg} \mathrm{ha}^{-1}, \mathrm{P}_{2} \mathrm{O}_{5} 40 \mathrm{~kg} \mathrm{ha}^{-1}$ and $\mathrm{K}_{2} \mathrm{O} 40 \mathrm{~kg} \mathrm{ha}^{-1}$ (Figure 7). Similarly, higher $\mathrm{RE}_{\mathrm{P}}$ of $76.8 \%$ with application of $210 \mathrm{~kg} \mathrm{~N} \mathrm{ha}^{-1}, 57.0 \%$ with application $40 \mathrm{~kg} \mathrm{P}_{2} \mathrm{O}_{5} \mathrm{ha}^{-1}$ and $66.4 \%$ with the application of $80 \mathrm{~kg} \mathrm{~K}_{2} \mathrm{O} \mathrm{ha}^{-1}$ was obtained whereas the lower value of $\mathrm{RE}_{\mathrm{P}}$ was recorded with the application of $\mathrm{N} 150 \mathrm{~kg} \mathrm{ha}^{-1}, \mathrm{P}_{2} \mathrm{O}_{5} 40 \mathrm{~kg} \mathrm{ha}^{-1}$ and $\mathrm{K}_{2} \mathrm{O}$ $40 \mathrm{~kg} \mathrm{ha}^{-1}(29.7 \%, 45.0 \%$ and $34.8 \%$, respectively).

With the use of $210 \mathrm{~kg} \mathrm{ha}^{-1}, \mathrm{P}_{2} \mathrm{O}_{5} 80 \mathrm{~kg} \mathrm{ha}^{-1}$ and $\mathrm{K}_{2} \mathrm{O}$ $60 \mathrm{~kg} \mathrm{ha}^{-1}$, higher $\mathrm{RE}_{\mathrm{K}}$ of $65.6 \%, 53.5 \%$ and $46.8 \%$, respectively were obtained whereas the lowest value of $24.9 \%, 33.6 \%$ and $43.8 \%$ were observed with the application of $\mathrm{N} 150 \mathrm{~kg} \mathrm{ha}^{-1}, \mathrm{P}_{2} \mathrm{O}_{5} 40 \mathrm{~kg} \mathrm{ha}^{-1}$ and $\mathrm{K}_{2} \mathrm{O} 40$ $\mathrm{kg} \mathrm{ha}^{-1}$, respectively.

\section{Agronomic Efficiency}

The hybrid maize recorded higher $\mathrm{AE}_{\mathrm{N}}$ of $25.3 \mathrm{~kg} \mathrm{~kg}^{-1}$, $25.0 \mathrm{~kg} \mathrm{~kg}^{-1}$ and $27.1 \mathrm{~kg} \mathrm{~kg}^{-1}$ with the application of $\mathrm{N} 210$ $\mathrm{kg} \mathrm{ha}^{-1}, \mathrm{P}_{2} \mathrm{O}_{5} 80 \mathrm{~kg} \mathrm{ha}^{-1}$ and $\mathrm{K}_{2} \mathrm{O} 80 \mathrm{~kg} \mathrm{ha}^{-1}$ while the lowest was observed from the application of $\mathrm{N} 150 \mathrm{~kg} \mathrm{ha}^{-1}(23.0$ $\left.\mathrm{kg} \mathrm{kg}^{-1}\right), \mathrm{P}_{2} \mathrm{O}_{5} 40 \mathrm{~kg} \mathrm{ha}^{-1}\left(22.6 \mathrm{~kg} \mathrm{~kg}^{-1}\right)$ and $\mathrm{K}_{2} \mathrm{O} 40 \mathrm{~kg} \mathrm{ha}^{-1}$ $\left(20.9 \mathrm{~kg} \mathrm{~kg}^{-1}\right)$ (Figure 8). The application of $\mathrm{N} 210 \mathrm{~kg} \mathrm{ha}^{-1}$, $\mathrm{P}_{2} \mathrm{O}_{5} 40 \mathrm{~kg} \mathrm{ha}^{-1}$ and $\mathrm{K}_{2} \mathrm{O} 80 \mathrm{~kg} \mathrm{ha}^{-1}$ resulted in the higher $\mathrm{AE}_{\mathrm{P}}$ of $61.2 \mathrm{~kg} \mathrm{~kg}^{-1}, 57.7 \mathrm{~kg} \mathrm{~kg}^{-1}$ and $55.7 \mathrm{~kg} \mathrm{~kg}^{-1}$, respectively, while the lowest values of $\mathrm{AE}_{\mathrm{P}}\left(31.9 \mathrm{~kg} \mathrm{~kg}^{-1}\right.$, $35.2 \mathrm{~kg} \mathrm{~kg}^{-1}$ and $35.4 \mathrm{~kg} \mathrm{~kg}^{-1}$ ) were found from the application of $\mathrm{N} 150 \mathrm{~kg} \mathrm{ha}^{-1}, \mathrm{P}_{2} \mathrm{O}_{5} 80 \mathrm{~kg} \mathrm{ha}^{-1}$ and $\mathrm{K}_{2} \mathrm{O} 40$ $\mathrm{kg} \mathrm{ha}^{-1}$, respectively.
At the same time, the higher $\mathrm{AE}_{\mathrm{K}}\left(65.0 \mathrm{~kg} \mathrm{~kg}^{-1}, 52.4 \mathrm{~kg}\right.$ $\mathrm{kg}^{-1}$ and $55.9 \mathrm{~kg} \mathrm{~kg}^{-1}$ ) were obtained with the application of N $210 \mathrm{~kg} \mathrm{ha}^{-1}, \mathrm{P}_{2} \mathrm{O}_{5} 80 \mathrm{~kg} \mathrm{ha}^{-1}$ and $\mathrm{K}_{2} \mathrm{O} 40 \mathrm{~kg} \mathrm{ha}^{-1}$, respectively whereas lower values were observed from $\mathrm{N}$ $210 \mathrm{~kg} \mathrm{ha}^{-1}\left(35.4 \mathrm{~kg} \mathrm{~kg}^{-1}\right), \mathrm{P}_{2} \mathrm{O}_{5} 40 \mathrm{~kg} \mathrm{ha}^{-1}\left(43.8 \mathrm{~kg} \mathrm{~kg}^{-1}\right)$ and $\mathrm{K}_{2} \mathrm{O} 80 \mathrm{~kg} \mathrm{ha}^{-1}\left(48.3 \mathrm{~kg} \mathrm{~kg}^{-1}\right)$.

The interactions of $\mathrm{N} \times \mathrm{P}, \mathrm{N} \times \mathrm{K}, \mathrm{P} \times \mathrm{K}$ and $\mathrm{N} \times \mathrm{P} \times \mathrm{K}$ on PFP, IE, PNB, RE, AE and PE in maize crop are presented in Table 1.

\section{Discussion}

\section{Nutrients and Grain yield}

Maize is grown in the mid-hills of Nepal during the monsoon season, when the amount and intensity of rainfall is high. The loss of nutrients by leaching is normal in areas with high rainfall. According to Thomison et al., (2004), excessive rainfall after planting often results in $\mathrm{N}$ loss through denitrification and leaching. The loss of nutrients reduces the maize production system's nutrient use efficiency, resulting in lower grain yields (Tadesse et al., 2013). Since fertilizer is relatively expensive when compared to produce, effective $\mathrm{N}$ fertilizer use is important for both agroeconomic and environmental reasons (Nyamangara et al., 2003). Fertilizer should be applied at the prescribed rate for optimum efficiency and productivity. Baral et al, 2020 observed encouraging results on hybrid maize (Khumal Hybrid-2) in Western Nepal that mostly focused on $\mathrm{N}$ application method. Their research results showed that deep placement of urea briquettes was found to be economic and it could replace $25 \%$ of $\mathrm{N}$ compared to the recommended practice. 


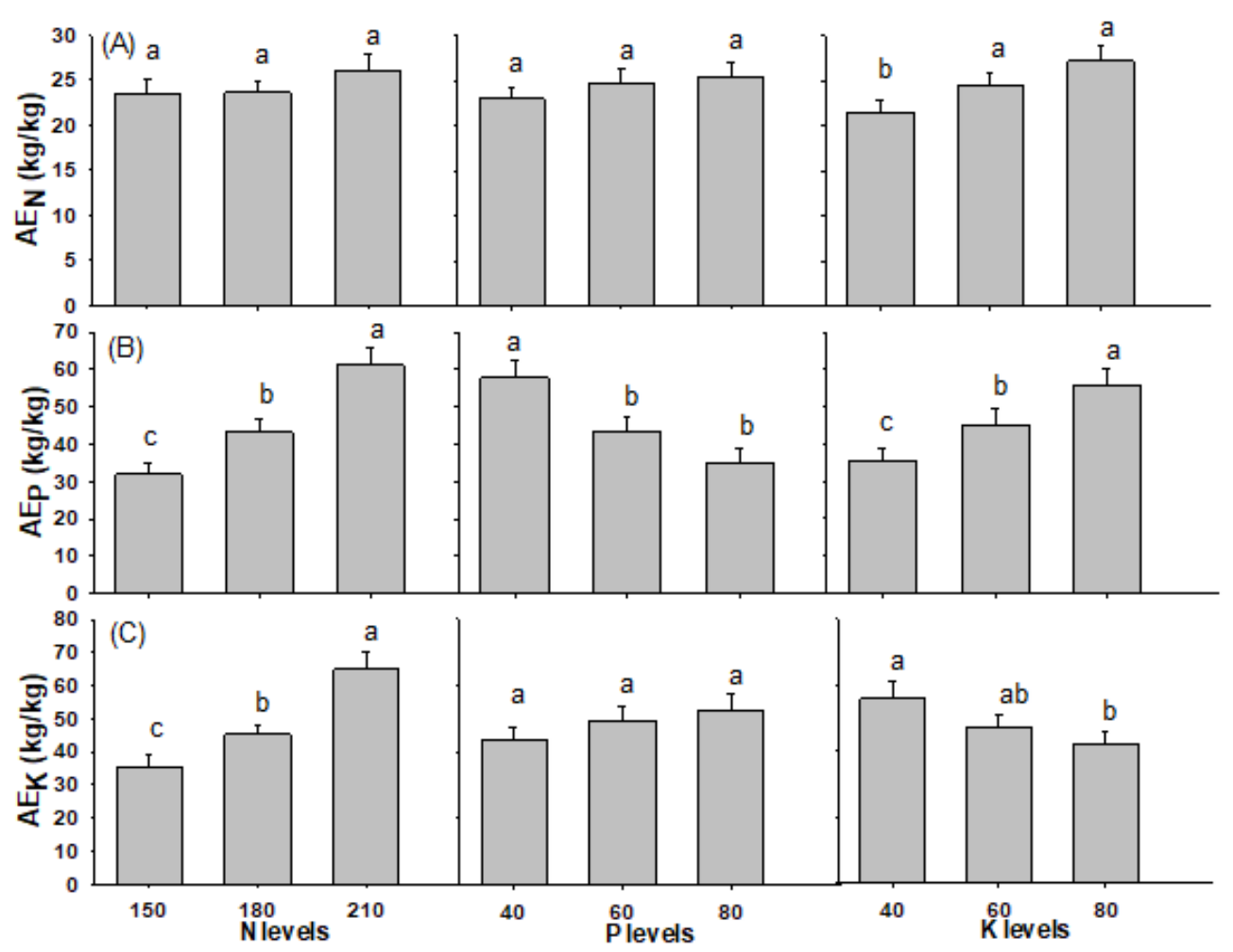

Figure 8. Agronomic Efficiency of hybrid maize (A) nitrogen (B) phosphorus (C) potassium as influenced by different levels of NPK fertilizer (2019-2020).

Different small alphabetical letters indicate significant differences at $\mathrm{P}<0.05$ (otherwise statistically at par). Bars indicate mean with standard error.

Table 1. Summary of analysis of variance (ANOVA) of $\mathrm{F}$ test Probability (P>F) (pooled data of two years)

\begin{tabular}{|c|c|c|c|c|c|c|c|c|c|}
\hline S.N & Parameters & Nutrient & $\mathrm{N}$ & $\mathrm{P}$ & $\mathrm{K}$ & $\mathrm{N} \times \mathrm{P}$ & $\mathrm{N} \times \mathrm{K}$ & $\mathrm{P} \times \mathrm{K}$ & $\mathrm{N} \times \mathrm{P} \times \mathrm{K}$ \\
\hline \multirow[t]{2}{*}{1} & \multirow[t]{2}{*}{ Grain yield } & & $* * *$ & NS & $* *$ & NS & NS & NS & $\mathrm{NS}$ \\
\hline & & $\mathrm{N}$ & $* * *$ & NS & $* *$ & $* *$ & NS & NS & NS \\
\hline \multirow[t]{2}{*}{2} & \multirow[t]{2}{*}{ PFP } & $\mathrm{P}$ & $* * *$ & $* * *$ & $* * *$ & $* *$ & NS & NS & NS \\
\hline & & K & $* * *$ & NS & $* * *$ & $* *$ & NS & NS & NS \\
\hline \multirow{3}{*}{3} & \multirow{3}{*}{ IE } & $\mathrm{N}$ & $* * *$ & $* *$ & $* * *$ & NS & NS & NS & NS \\
\hline & & $\mathrm{P}$ & $* * *$ & $* *$ & $*$ & $* *$ & NS & NS & NS \\
\hline & & $\mathrm{K}$ & $*$ & $*$ & $*$ & NS & NS & NS & NS \\
\hline \multirow{3}{*}{4} & \multirow{3}{*}{ PNB } & $\mathrm{N}$ & $*$ & $* *$ & $* *$ & $* *$ & NS & NS & NS \\
\hline & & $\mathrm{P}$ & $* * *$ & $* * *$ & $* * *$ & NS & NS & NS & $*$ \\
\hline & & $\mathrm{K}$ & $* * *$ & * & $* * *$ & $*$ & NS & NS & NS \\
\hline \multirow{3}{*}{5} & \multirow{3}{*}{ RE } & $\mathrm{N}$ & $* * *$ & $* *$ & $* * *$ & $* * *$ & NS & NS & $* *$ \\
\hline & & $\mathrm{P}$ & $* * *$ & NS & $* * *$ & $*$ & NS & NS & $*$ \\
\hline & & $\mathrm{K}$ & $* * *$ & NS & NS & NS & NS & NS & NS \\
\hline \multirow{3}{*}{6} & \multirow{3}{*}{$\mathrm{AE}$} & $\mathrm{N}$ & NS & NS & $* *$ & $* *$ & NS & NS & NS \\
\hline & & $\mathrm{P}$ & $* * *$ & $* *$ & $* * *$ & $* *$ & NS & NS & NS \\
\hline & & K & $* * *$ & NS & $*$ & $* *$ & NS & NS & NS \\
\hline \multirow{3}{*}{7} & \multirow{3}{*}{ PE } & $\mathrm{N}$ & $* *$ & $\mathrm{NS}$ & NS & NS & NS & $\mathrm{NS}$ & $\mathrm{NS}$ \\
\hline & & $\mathrm{P}$ & NS & $* *$ & NS & $*$ & NS & NS & $*$ \\
\hline & & $\mathrm{K}$ & $*$ & $*$ & $*$ & NS & NS & NS & NS \\
\hline
\end{tabular}

NS=non-significant $(\mathrm{P}>-0.05) ; * * *=$ significant at $0.1 \% ; *=$ significant at $1 \%$ and $*=$ significant at $5 \%$

The grain yield was influenced by $\mathrm{N}$ and $\mathrm{K}$ levels for two years, with an average of 9.98 ton/ha. Similar to our findings, Rutkowska et al., (2014) discovered that combining $\mathrm{K}$ fertilizer with nitrogen fertilization in the range of $150-250 \mathrm{~kg} \mathrm{~N} / \mathrm{ha}$ resulted in a $9 \mathrm{t} / \mathrm{ha}$ corn yield. The level of nitrogen supply influences the yield response to potassium fertilization to a large extent (Brennan and Bolland 2009). Enhanced nitrogen and potassium application increased nutrient availability in the soil and nitrogen and potassium uptake in the maize plant, resulting in an increase in maize grain production. And that might be the reason why the grain yield of Khumal Hybrid-2 was maximum when $\mathrm{N}$ was at $210 \mathrm{~kg} \mathrm{ha}^{-1}$ and $\mathrm{K}_{2} \mathrm{O}$ was at 80 $\mathrm{kg} \mathrm{ha}^{-1}$. However, due to higher $\mathrm{P}$ availability in the soil, there was no significant increase of phosphorus beyond 40 $\mathrm{kg} \mathrm{P}_{2} \mathrm{O}_{5} \mathrm{~kg} \mathrm{ha}^{-1}$. It may be the result of carryover effects of residual $\mathrm{P}$ from previous $\mathrm{P}$ fertilizer applications before planting. Increased nitrogen rates increased maize grain yield, according to Seadh et al., (2013) and Adhikary and Adhikary (2013). K treatment enhanced grain production due to improvements in prolificacy and grain weight, according to Ahmad et al., (2009) and Liaqat et al., (2018). 


\section{Partial Factor Productivity}

The partial factor productivity index is a reliable way to compare the economic benefits of fertilization in different areas. $\mathrm{PFP}_{\mathrm{N}}$ was higher when $\mathrm{N}$ application rates were low and it decreased as $\mathrm{N}$ levels increased, similar to findings of Khalili et al., (2018), but it increased with increased in PK levels and vice versa. In the case of $\mathrm{PFN}_{\mathrm{P}}$ and $\mathrm{PFP}_{\mathrm{K}}$, a similar pattern was observed which is in agreement with that of Ray et al., (2017). Variations in average PFP between regions rely on yield potential, soil quality, amount and form of fertilizer application and other crop management operations including overall timeliness and quality, according to Dobermann and Cassman (2005). On average, $\operatorname{PFP}_{\mathrm{N}}\left(55.9 \mathrm{~kg} \mathrm{~kg}^{-1}\right), \operatorname{PFP}_{\mathrm{P}}\left(179.1 \mathrm{~kg} \mathrm{~kg}^{-1}\right)$ and PFP $_{\mathrm{K}}\left(177.7 \mathrm{~kg} \mathrm{~kg}^{-1}\right)$ observed in our study was within the benchmarks (40-90 kg kg-1, 100-250 kg kg-1 and 75-200 kg $\mathrm{kg}^{-1}$, respectively) documented by Fixen et al., (2015). The average $\mathrm{PFP}_{\mathrm{N}}$ in our study is similar to the value of $62 \mathrm{~kg}$ $\mathrm{kg}^{-1}$ recorded by Baral et al., (2020), the value of $63.0 \mathrm{~kg}$ $\mathrm{kg}^{-1}$ observed by Xu et al., (2017), and the value of $\mathrm{PFP}_{\mathrm{N}}$ $>60 \mathrm{~kg} \mathrm{~kg}^{-1}$ obtained by Dobermann (2007) in well managed systems. These findings support those of Sharifi and Namvar (2016), and Nemati and Sharifi (2012), who found that increasing fertilizer rates decreases NUE because yield rises slower than $\mathrm{N}$ supply in soil and fertilizer.

\section{Partial Nutrient Budget}

$\mathrm{PNB}_{\mathrm{N}}, \mathrm{PNB}_{\mathrm{P}}$, and $\mathrm{PNB}_{\mathrm{K}}$ were higher when corresponding $\mathrm{N}, \mathrm{P}, \mathrm{K}$ application rates were low and decreased as nutrient levels increased with the mean values $0.95 \mathrm{~kg} \mathrm{~kg}^{-1}, 1.81 \mathrm{~kg} \mathrm{~kg}^{-1}$ and $1.67 \mathrm{~kg} \mathrm{~kg}^{-1}$, respectively. These values were higher than the benchmarks values of $0.7-0.9 \mathrm{~kg} \mathrm{~kg}^{-1}$ as recorded by Fixen et al., (2015). PNB values greater than one signifies the requirement for fertility replenishment from $\mathrm{N}, \mathrm{P}$, and $\mathrm{K}$ fertilization as suggested by Ray et al., (2017). Snyder and Bruulsema (2007) recommended that PNB is $>1$ in nutrient-deficient systems (fertility improvement), $<1$ in nutrient-surplus systems (under-replacement), and is significantly less than $1: 1$ in sustainable systems. Our findings showed that amount of nutrient uptake was higher than the amount of nutrient supplied through fertilizer in case of $\mathrm{P}$ and $\mathrm{K}$ which might not be sustainable system. Improvement of nutrient through application of additional fertilizer and decreasing the loss of nutrient through management practices should be done to make it sustainable.

\section{Internal Efficiency}

Internal efficiency is a measurement of a plant's ability to convert nutrients from all sources (soil and fertilizer) into economic yield (grain) as described by Liu et al., (2011). A low IE indicates that internal nutrient conversion is poor and vice-versa. $\mathrm{IE}_{\mathrm{N}}$ ranged from 55.4 to $63.1 \mathrm{~kg} \mathrm{~kg}$ ${ }^{1}$, with a mean of $59.1 \mathrm{~kg} \mathrm{~kg}^{-1}$, which is within the range of IE reported by Pathak et al., (2003) in cereal-based systems (18.3-65.9 kg kg-1), similar to the optimal range of $\mathrm{IE}_{\mathrm{N}}(55$ to $65 \mathrm{~kg} \mathrm{~kg}^{-1}$ ) for balanced nutrition at higher yield as recorded by Dobermann (2007) and higher than average $\mathrm{IE}_{\mathrm{N}}\left(44.4 \mathrm{~kg} \mathrm{~kg}^{-1}\right)$ recorded by Xu et al., (2017). The $\mathrm{IE}_{\mathrm{P}}$ averaged $98.24 \mathrm{~kg} \mathrm{~kg}^{-1}$ and $\mathrm{IE}_{\mathrm{K}}$ averaged $112.8 \mathrm{~kg} \mathrm{~kg}^{-1}$ in hybrid maize in mid hill condition.

\section{Physiological Efficiency}

The increase in yield in proportion to the change in crop uptake of the nutrient in above-ground sections of the plant is expressed as PE. It's similar to $\mathrm{AE}$ and $\mathrm{RE}$. On average, $\mathrm{PE}_{\mathrm{N}}$ of $43.28 \mathrm{~kg} \mathrm{~kg}^{-1}, \mathrm{PE}_{\mathrm{P}}$ of $106.5 \mathrm{~kg} \mathrm{~kg}^{-1}$ and $\mathrm{PE}_{\mathrm{K}}$ of 137.5 $\mathrm{kg} \mathrm{kg}^{-1}$ were observed in our study in which PE for all the three nutrients were poor for the treatments where N, P and $\mathrm{K}$ application was high and vice-versa. The low $\mathrm{PE}$ indicates that accumulation of nutrients (input) was higher than the grain yield (output). Amado et al., (2017) observed $\mathrm{PE}_{\mathrm{N}}$ was higher when $\mathrm{N}$ application rates were low and it decreased as $\mathrm{N}$ levels increased, similar to our findings. The researchers recorded $\mathrm{PE}_{\mathrm{N}}$ value of $40 \mathrm{~kg} \mathrm{~kg}^{-1}$ from the application of $\mathrm{N} @ 180 \mathrm{~kg} \mathrm{ha}^{-1}$, which is comparable to our report, which obtained $\mathrm{PE}_{\mathrm{N}}$ value of $43.4 \mathrm{~kg} \mathrm{~kg}^{-1}$ at the same rate of nitrogen application. The $\mathrm{PE}_{\mathrm{N}}$ obtained in our study was same as maximum $\mathrm{PE}_{\mathrm{N}}\left(42.95 \mathrm{~kg} \mathrm{~kg}^{-1}\right)$ observed by Niaz et al., (2015) and greater than the value of $37 \mathrm{~kg}$ $\mathrm{kg}^{-1}$ published by Ladha et al., (2005) and maximum value of $31.63 \mathrm{~kg} \mathrm{~kg}^{-1}$ recorded by Goshu et al., (2019).

\section{Recovery Efficiency}

Despite the fact that large quantities of $\mathrm{N}$ fertilizers were used all over the world, crop recovery or efficiency of $\mathrm{N}$ fertilizers in agricultural production is poor, ranging from $25 \%$ to $50 \%$ of the applied N (Chien et al., 2016; Dobermann et al., 2003). Excessive rainfall occurred during maize season might have caused nitrate leaching or denitrification, which may be the primary cause of $\mathrm{N}$ loss. The $\mathrm{RE}_{\mathrm{N}}, \mathrm{RE}_{\mathrm{P}}$, and $\mathrm{RE}_{\mathrm{K}}$ values of $57.4,50.7 \%$, and $44.0 \%$ falls within the range of RE obtained $(31.2 \%$ to $105.6 \%)$ by Ray et al., (2017), and Fosu-Mensah and Mensah (2016) observed $\mathrm{RE}_{\mathrm{N}}$ ranged from 23.5 to $73.1 \%$ during their experiment in maize crop. In this experiment, mean $R_{N}$ was found to similar to previous studies recorded by Ladha et al., (2016) who recorded the highest value of $\mathrm{RE}_{\mathrm{N}}(57 \%$ of the crop $\mathrm{N}$ harvest) in maize among the cereals and higher than the target value of $50 \%$ suggested by Dobermann (2007). The relatively higher values of RE might be due to residual nutrients from previous crops and soil indigenous nutrient supply. The higher the rate of $\mathrm{N}$ application, higher was the uptake of $\mathrm{N}$ by the crop, therefore high value of $\mathrm{RE}_{\mathrm{N}}$ was observed with high level of nitrogen which is in the line with Keeney (1982) who observed that NUE was increased by providing as much nitrogen as the crop needs. $\mathrm{RE}_{\mathrm{P}}$ and $\mathrm{RE}_{\mathrm{K}}$ of hybrid maize decreased with further addition of $\mathrm{P}$ and $\mathrm{K}$ which might be because of diminishing returns. Smil (2000) documented that $45 \%$ of $\mathrm{P}$ fertilizer is taken up by the crops, similar to our average $\mathrm{RE}_{\mathrm{P}}$ in maize plant. The range of $\mathrm{RE}_{\mathrm{K}}$ recorded in our study correlates the findings of Ghosh et al. (2015) in which the amount of applied $\mathrm{K}$ recovered in the first year can range from $20 \%$ to $60 \%$.

\section{Agronomic Efficiency}

Agronomic efficiency which indicates how much yield is enhanced for additional unit of nutrients. The $\mathrm{AE}_{N}, \mathrm{AE}_{\mathrm{P}}$ and $\mathrm{AE}_{\mathrm{K}}$ affected by the NPK levels ranged from 23.0 to $27.2 \mathrm{~kg} \mathrm{~kg}^{-1}, 31.9$ to $61.2 \mathrm{~kg} \mathrm{~kg}^{-1}$ and 35.4 to $65.0 \mathrm{~kg} \mathrm{~kg}^{-1}$ with the mean value of $24.4,45.4$ and $48.5 \mathrm{~kg} \mathrm{~kg}^{-1}$, respectively. $\mathrm{AE}_{\mathrm{N}}$ measured in the current study is lower than the value $\left(37 \mathrm{~kg} \mathrm{~kg}^{-1}\right)$ recorded by Duan et al., (2014) and similar to $\mathrm{AE}_{\mathrm{N}}\left(24.7 \mathrm{~kg} \mathrm{~kg}^{-1}\right)$ recorded by $\mathrm{Xu}$ et al., 
(2017). Dobermann et al., (2007) suggested the target value $\left(25 \mathrm{~kg} \mathrm{~kg}^{-1}\right)$ in maize who observed that the $\mathrm{AE}_{\mathrm{N}}$ in cereals ranges from 10 to $30 \mathrm{~kg} \mathrm{~kg}^{-1}$ and can only be $>30 \mathrm{~kg} \mathrm{~kg}^{-1}$ in well-managed systems with low $\mathrm{N}$ fertilizer amounts or a low soil $\mathrm{N}$ supply. Our findings are in agreement with that of Ray et al., (2017) found the $\mathrm{AE}_{\mathrm{N}}$ varied from 5.6 to 23.6 $\mathrm{kg} \mathrm{kg}^{-1}$ and Baral et al., (2020) recorded similar $\mathrm{AE}_{\mathrm{N}}$ values of $30.2 \mathrm{~kg} \mathrm{~kg}^{-1}$. The higher $\mathrm{AE}_{\mathrm{P}}$ and $\mathrm{AE}_{\mathrm{K}}$ with lower doses of $\mathrm{P}$ and $\mathrm{K}$ respectively were obtained in our study, similar to the findings of $\mathrm{Xu}$ et al., (2014). The higher the rate of $\mathrm{N}$ application, higher was the grain yield of the maize crop, therefore high value of $\mathrm{AE}_{\mathrm{N}}$ was observed with high level of nitrogen. Similar to our finding, Khalili et al., (2018) and Niaz et al., (2015) recorded that higher the nitrogen rate, greater the $\mathrm{AE}_{\mathrm{N}}$. In the present study, the $\mathrm{AE}_{\mathrm{P}}$ was poor for the treatments where $\mathrm{N}$ and $\mathrm{K}$ application were low and $\mathrm{AE}_{\mathrm{K}}$ was low when $\mathrm{N}$ and $\mathrm{P}$ were used in lower rates. The results of this research as well as the findings of Kurwakumire et al., (2014) confirms that choosing a balanced fertilizer combination that attains the highest agronomic efficiency of each nutrient is critical.

It is appropriate to revise the dose of fertilizer as N 210 $\mathrm{kg} \mathrm{ha}^{-1}$ and $\mathrm{K}_{2} \mathrm{O} 80 \mathrm{~kg} \mathrm{ha}^{-1}$ were optimum for higher maize production with grain yield of $10.95 \mathrm{t} / \mathrm{ha}$ and 10.54 ton/ha, respectively in silty clay loam soil condition of mid hill of Nepal. The use of higher rate of inorganic $\mathrm{P}$ and $\mathrm{K}$ fertilizer improved the efficiencies of $\mathrm{N}$ by the maize and the case was also valid for efficiencies of P and $\mathrm{K}$. N $150 \mathrm{~kg} \mathrm{ha}^{-1}$ resulted the highest $\mathrm{PFP}_{\mathrm{N}}, \mathrm{PNB}_{\mathrm{N}}, \mathrm{IE}_{\mathrm{N}}$ and $\mathrm{PE}_{\mathrm{N}}$ whereas $\mathrm{N}$ $210 \mathrm{~kg} \mathrm{ha}^{-1}$ showed the higher $\mathrm{AE}_{\mathrm{N}}$ and $\mathrm{RE}_{\mathrm{N}}$. These findings can help to direct the use of chemical fertilizers in maize-based cropping systems thereby maintaining nutrient use efficiency. This form of research should be carried out in a variety of soil types, different varieties and agro-ecologies in order to establish a efficient nutrient management strategy in Nepal.

\section{Acknowledgements}

The authors would like to thank the National Soil Science Research Center and the National Agronomy Research Center in Khumaltar for providing the necessary facilities and support for the research to be completed successfully. We are appreciative for the financial support provided by the Nepal Agricultural Research Council and NSAF/CIMMYT in carrying out the research program.

\section{Conflicts of Interest}

The author declares no conflict of interest.

\section{References}

Adhikary BH, Adhikary R. 2013. Enhancing effect of nitrogen on grain production of hybrid maize in Chitwan valley. Agronomy Journal of Nepal. 3:33-41.

Ahmad M, Riaz A, Ishaque M, Malik AU. 2009. Response of maize hybrids to varying potassium application in Pakistan. Pakistan Journal of Agricultural Sciences. 46(3):179-184.

Amado TJC, Villalba EOH, Bortolotto RP, Nora DD, Bragagnolo J, León EAB. 2017. Yield and nutritional efficiency of corn in response to rates and splits of nitrogen fertilization. Revista Ceres. 64(4):351-359.
Asghar A, Ali A, Syed WH, Asif M, Khaliq T, Abid AA. 2010. Growth and yield of maize (Zea mays L.) cultivars affected by NPK application in different proportion. Pakistan journal of Science. 62(4):211-216.

Banerjee H, Goswami R, Chakraborty S, Dutta S, Majumdar K, Satyanarayana T, Jat ML, Zingore S. 2014. Understanding biophysical and socio-economic determinants of maize (Zea mays L.) yield variability in eastern India. NJASWageningen Journal of Life Sciences. 70:79-93.

Baral BR, Pokhrel KR, Pandit NR, Thapa SB, Gaihre YK, \& Vista SP. 2020. Deep placement of briquetted urea increases agronomic and economic efficiency of maize in sandy loam soil. AGRIVITA, Journal of Agricultural Science. 42(3).

Bolland MDA, Gilkes RJ. 1998. The chemistry and agronomic effectiveness of phosphate fertilisers. In 'Nutrient use in crop production'. (Ed. Z Rengel). 139-163.

Brar MS, Bijay-Singh Bansal SK, Srinivasarao Ch. 2011. Role of Potassium Nutrition in Nitrogen Use Efficiency in Cereals. Research Findings: e-ifc No. 29.

Bremner JM. 1996. Nitrogen-total. Methods of soil analysis: Part 3 Chemical methods 5:1085-1121.

Brennan RF, Bolland MDA. 2009. Comparing the nitrogen and potassium requirements of canola and wheat for yield and grain quality. Journal of Plant Nutrition. 32(12):2008-2026.

Bukhsh MAAHA, Ahmad R, Iqbal J, Maqbool MM, Ali A, Ishaque M, Hussain S. 2012. Nutritional and physiological significance of potassium application in maize hybrid crop production. Pakistan Journal of Nutrition. 11(2):187.

Chien SH, Teixeira LA, Cantarella H, Rehm GW, Grant CA, Gearhart MM. 2016. Agronomic effectiveness of granular nitrogen/phosphorus fertilizers containing elemental sulfur with and without ammonium sulfate: A review. Agronomy Journal. 108(3):1203-1213.

Coelho AM, de França GE, Pitta GVE, Alves VMC, Hernani LC. 2008. Fertilidade de solos: nutrição e adubação do milho. Embrapa Milho e Sorgo-Capítulo em livro científico (ALICE)

Delve RJ, Probert ME, Cobo JG, Ricaurte J, Rivera M, Barrios E, Rao IM. 2009. Simulating phosphorus responses in annual crops using APSIM: model evaluation on contrasting soil types. Nutrient cycling in agroecosystems. 84(3):293-306.

Dhillon, J., Torres, G., Driver, E., Figueiredo, B., Raun, W. R. 2017. World phosphorus use efficiency in cereal crops. Agronomy Journal 109(4): 1670-1677.

Dobermann A. 2007. Nutrient use efficiency - measurement and management. In "IFA International Workshop on Fertilizer Best Management Practices", Brussels, Belgium 1-28.

Dobermann, A., Cassman, K. G. 2005. Cereal area and nitrogen use efficiency are drivers of future nitrogen fertilizer consumption. Science in China Series C: Life Sciences 48(2): 745-758.

Dobermann A, Ping JL, Adamchuk VI, Simbahan GC, Ferguson RB. 2003. Classification of crop yield variability in irrigated production fields. Agronomy Journal. 95(5):1105-1120.

Duan Y, Xu M, Gao S, Yang X, Huang S, Liu H, Wang B. 2014. Nitrogen use efficiency in a wheat-corn cropping system from 15 years of manure and fertilizer applications. Field Crops Research. 157:47-56.

Fixen P, Brentrup F, Bruulsema T, Garcia F, Norton R, Zingore S. 2015. Nutrient/fertilizer use efficiency: measurement, current situation and trends. Managing water and fertilizer for sustainable agricultural intensification. 270.

Fixen PE. 2010. The four rights within a global fertilizer best managament practices framework. Boas praticas para uso eficiente de fertilizantes. Piracicaba, International Plant Nutrition Institute. 01-22.

Fosu-Mensah BY, Mensah M. 2016. The effect of phosphorus and nitrogen fertilizers on grain yield, nutrient uptake and use efficiency of two maize (Zea mays L.) varieties under rain fed condition on Haplic Lixisol in the forest-savannah transition zone of Ghana. Environmental Systems Research. 5(1):1-17. 
Ghosh BN, Singh RJ, Mishra PK. 2015 Soil and input management options for increasing nutrient use efficiency. Nutrient use efficiency: from basics to advances. 17-27.

Gomez KA, Gomez AA. 1984. Statistical procedures for agricultural research. 2nd Ed. John Wiley \& Sons, New York.

Goshu TA, Gissa DW, Dalessa TD. 2019. Nitrogen Use Efficiency and Yield of Maize Varieties as affected by Nitrogen rate in Mid Altitude Areas of Western Ethiopia. 2019020239 (doi: 10.20944/preprints201902.0239.v1)

Huang, P., Zhang, J., Zhu, A., Li, X., Ma, D., Xin, X., ... \& Pereira, E. I. P. (2018). Nitrate accumulation and leaching potential reduced by coupled water and nitrogen management in the Huang-Huai-Hai Plain. Science of the Total Environment, 610, 1020-1028.

Jackson ML. 1973. Methods of chemical analysis. Prentic Hall., EngleWood Cliffs, NTJ.

Jordan-Meille L, Pellerin S. 2008. Shoot and root growth of hydroponic maize (Zea mays L.) as influenced by $\mathrm{K}$ deficiency. Plant and Soil. 304(1):157-168.

Keeney DR. 1982. Nitrogen management for maximum efficiency and minimum pollution. Nitrogen in agricultural soils. 22:605-649.

Khalili A, Dhar S, Dass A, Ahmad Faiz M, Varghese E. 2018. Agronomic indices of nitrogen use efficiency and maize yield response to various rates, time of application and their interaction effect in Kandahar region of Afghanistan. Agronomic indices of nitrogen use efficiency and maize yield response. Annals of Agricultural Research. 39(4):347-353.

Khatri-Chhetri TB. 1991. Introduction to soils and soil fertility. Tribhuvan University, Institute of Agriculture and Animal Science, Rampur, Chitwan, Nepal.

Kurwakumire N, Chikowo R, Mtambanengwe F, Mapfumo P, Snapp S, Johnston A, Zingore S. 2014. Maize productivity and nutrient and water use efficiencies across soil fertility domains on smallholder farms in Zimbabwe. Field Crops Research. 164:136-147.

Ladha JK, Pathak H, Krupnik TJ, Six J, van Kessel C. 2005. Efficiency of fertilizer nitrogen in cereal production: retrospects and prospects. Advances in agronomy. 87:85-156.

Ladha JK, Tirol-Padre A, Reddy CK, Cassman KG, Verma S, Powlson DS, Van Kessel C, Richter DDB, Chakraborty D, Pathak H. 2016. Global nitrogen budgets in cereals: A 50-year assessment for maize, rice and wheat production systems. Scientific reports 6(1):1-9.

Liaqat W, Jan MF, Ahmad H, Khan EH, Khan N, Rehan W. 2018. Impact of mineral potassium on phenology, growth and yield of maize hybrid. International Journal of Environmental Sciences \& Natural Resources. 8(5):168-171.

Liu X, He P, Jin J, Zhou W, Sulewski G, Phillips S. 2011. Yield gaps, indigenous nutrient supply, and nutrient use efficiency of wheat in China. Agronomy journal. 103(5):1452-1463.

Minjian C, Haiqiu Y, Hongkui Y, Chunji J. 2007. Difference in tolerance to potassium deficiency between two maize inbred lines. Plant Production Science. 10(1):42-46.

Nemati AR, Sharifi RS. 2012. Effects of rates and nitrogen application timing on yield, agronomic characteristics and nitrogen use efficiency in corn. International Journal of Agriculture and Crop Sciences (IJACS). 4(9):534-539.

Niaz A, Yaseen M, Arshad M, Ahmad R. 2015. Response of maize yield, quality and nitrogen use efficiency indices to different rates and application timings. Journal of Animal and Plant Sciences. 25(4):1022-1031.

Nyamangara J, Bergström LF, Piha MI, Giller KE. 2003. Fertilizer use efficiency and nitrate leaching in a tropical sandy soil. Journal of environmental quality. 32(2):599-606.

Pathak H, Singh Y, Singh B. 2003. Site-specific nutrient management for improving the productivity of rice-wheat cropping system. In Nutrient Management for Sustainable Rice-wheat Cropping System, 79-98 (Eds Y. Singh, B. Singh, V. K. Nayyar, and J. Singh). New Delhi, India: National Agricultural Technology Project, Indian Council of Agricultural Research.
Potash and Phosphate Institute (PPI). 2003. Effect of Foliar applied monopotassium phosphate on high yielding Canola and Wheat Grown in Southern Manitoba.

Raun WR, Johnson G. 1999. Improving nitrogen use efficiency for cereal production. Agronomy Journal. 91(3):357-363.

Ray K, Banerjee H, Bhattacharyya K, Dutta S, Phonglosa A, Pari A, Sarkar S. 2017. Site-specific nutrient management for hybrids in an inceptisol of West Bengal, India. Exp. Agric. 54:874-887.

Rehman A, Saleem MF, Safdar ME, Hussain S, Akhtar N. 2011. Grain quality, nutrient use efficiency, and bioeconomics of maize under different sowing methods and NPK levels. Chilean journal of agricultural research. 71(4):586.

Rutkowska A, Pikuła D, Stępień W. 2014. Nitrogen use efficiency of maize and spring barley under potassium fertilization in long-term field experiment. Plant, Soil and Environment. 60(12):550-554.

Seadh SE, Attia AN, El-Moursy SA, Said EM, El-azab AAS. 2013. Productivity of maize as affected by organic, foliar and nitrogen fertilization levels. World Research Journal of Agronomy. 2(1):30-36.

Sharifi RS, Namvar A. 2016. Effects of time and rate of nitrogen application on phenology and some agronomical traits of maize (Zea mays L.). Biologija. 62(1).

Smil V. 2000. Phosphorus in the environment: natural flows and human interferences. Annual review of energy and the environment. 25(1):53-88.

Smil V. 2002. Nitrogen and food production: proteins for human diets. AMBIO: A Journal of the Human Environment. 31(2):126-131.

Snyder CS, Bruulsema TW. 2007. Nutrient use efficiency and effectiveness in North America. Publ. Int. Plant Nutr. Inst. IPNI.

Steel RGD, Torrie JH, Dicky DA. 1997. Principles and Procedures of Statistics, A Biometrical Approach. 3rd Edition, McGraw Hill, Inc. Book Co., New YorkSyers, J. K., Johnston, A. E., \& Curtin, D. (2008). Efficiency of soil and fertilizer phosphorus use. FAO Fertilizer and plant nutrition bulletin, 18(108).

Tadesse T, Assefa A, Liben M, Tadesse Z. 2013. Effects of nitrogen split-application on productivity, nitrogen use efficiency and economic benefits of maize production in Ethiopia. International Journal of Agricultural Policy and Research. 1(4):109-115.

Tetarwal JP, Ram B, Meena DS. 2011. Effect of integrated nutrient management on productivity, profitability, nutrient uptake and soil fertility in rainfed maize (Zea mays). Indian journal of Agronomy. 56(4):373-376.

Thomison PR, Geyer AB, Bishop BL, Young JR, Lentz E. 2004. Nitrogen fertility effects on grain yield, protein, and oil of corn hybrids with enhanced grain quality traits. Crop Management. 3(1):1-7.

Uribelarrea M, Crafts-Brandner SJ, Below FE. 2009. Physiological N response of field-grown maize hybrids (Zea mays L.) with divergent yield potential and grain protein concentration. Plant and soil. 316(1):151-160.

Xu C, Huang S, Tian B, Ren J, Meng Q, Wang P. 2017. Manipulating planting density and nitrogen fertilizer application to improve yield and reduce environmental impact in Chinese maize production. Frontiers in plant science. 8:1234.

Xu X, He P, Pampolino MF, Johnston AM, Qiu S, Zhao S, Chuan L, Zhou W. 2014 Fertilizer recommendation for maize in China based on yield response and agronomic efficiency. Field Crops Research. 157:27-34. 